\title{
INSULIN RECEPTOR AND ITS RELATIONSHIP WITH DIFFERENT FORMS OF INSULIN RESISTANCE
}

\author{
Aleksandra ROJEK, Marek NIEDZIELA \\ Department of Pediatric Endocrinology and Diabetology, II Chair of Pediatrics, \\ Poznan University of Medical Sciences
}

DOI: $10.2478 / \mathrm{v} 10052-010-0004-8$

Summary: Insulin plays an important role in maintaining the whole organism's homeostasis. The presence of insulin receptors in all vertebrates and invertebrates cells reflects the diversity of regulatory processes in which this hormone is involved. Furthermore, many different factors may influence the level of insulin receptor expression. These factors include e.g. the sole insulin or stage of development. Mutations in the receptor may lead to the development of insulin resistance. These mutations differ in the level of severity and are frequently associated with diabetes mellitus, hypertension, cardiovascular disorders, heart failure, metabolic syndrome and infertility in women. More than 50 mutations in insulin receptor gene have already been characterized. These mutations are associated with rare forms of insulin resistance like leprechaunism, insulin resistance type A or Rabson-Mendenhall syndrome. Molecular analysis of insulin receptor gene may lead to a better understanding of molecular mechanisms underlying various types of insulin resistance and help to develop more efficient treatment.

Key words: insulin receptor, INSR gene, alternative splicing, insulin receptor isoforms, hybrid receptors, insulin resistance.

Abbreviations: RMS - Rabson-Mendenhall Syndrome; INSR - insulin receptor gene; INSR - insulin receptor gene's transcript or insulin receptor; PCOS - polycystic ovary syndrome; SNP - single nucleotide polymorphism; EGFR - epidermal growth factor; C/EBP $\boldsymbol{\beta}$ - CAAT/enhancer binding protein $\beta$; TBP - TATA binding protein; TAFs - TATA associated factors; GRE - glucocorticoid response element; CAT - chloramphenicol acetylotransferase; EMSA - electrophoretic mobility shift assay; IR-DBP - insulin receptor DNA binding protein; HMGI-Y - high mobility group; HT-FIR hepatocyte-specific transcription factor of the insulin receptor gene; IGF-I, IGF-II - insulin-like growth factor I, II; ISE - intronic sequence enhancer; ESE - exonic sequence enhancer; ISS intronic sequence silencer; ESS - exonic sequence silencer; 5', 3'UTR - 5', 3' untranslated region; pre-mRNA - precursor-messenger RNA; BP - branch point; U1snRNP - U-rich 1 small nuclear ribonucleoprotein particle; SF2/ASF - splicing factor 2/alternative splicing factor; hnRNP-A1, F heterogenous nuclear ribonucleoprotein A1, F; IRS - insulin receptor substrate; APS -adaptor protein; PI3K - phosphatidylinositol 3-kinase; PIP2 - phosphatidylinositol 4,5-bisphosphate; PIP3 phosphatidylinositol 3,4,5-triphosphate; GLUT4 - glucose transporter 4; Grb-2 - growth factor 
receptor-binding protein 2; ATP - adenosinotrisphosphate; LRR -leucine-rich repeat; $\mathbf{C R}$ - cysteine rich; FU - furin-like; Fn0, Fn1, Fn2 - fibronectin type III; TM - transmembrane domain; JM juxtamembrane domain; TK - tyrosine kinase domain; CT - carboxyterminal tail; ER endoplasmatic reticulum; Grp94 - glucose-regulated protein; kDa - kilodalton; HSP90 - heat shock protein $90 ; \mathbf{E 1 1}^{+}$- transcript of the insulin receptor gene containing alternative exon 11 or a protein encoded by this transcript; $\mathbf{E 1 1}^{-}$- transcript of the insulin receptor gene without alternative exon 11 or a protein encoded by this transcript; IgG - immunoglobulin G; Met - methionine; VLDL - very low density lipoproteins; CGL - congenital generalized lipodystrophy; FPL - familial partial lipodystrophy; AGPAT2 - 1-acylglycerol-3-phosphate-O-acyltransferase 2; BSCL2 -BerardinelliSeip Congenital Lipodystrophy type 2; PPAR $\gamma$ - peroxisome proliferator-activated receptor gamma; ZMPSTE24 - zinc metalloproteinase, STE24 Saccharomyces cerevisiae homologue

\section{INTRODUCTION}

Insulin signal transduction pathways play important roles in maintaining the cellular homeostasis through regulation of glucose metabolism, glycogen synthesis, lipids and proteins metabolism, ions and amino-acids transport, control of cell cycle, proliferation and cell differentiation in addition to gene transcription and nitrogen oxide synthesis.

The presence of insulin receptors in most vertebrate cells further reflects the diversity of regulatory processes in which insulin is involved. However, it was noted that several factors may influence the level of insulin receptor expression, including the sole insulin, glucocorticoids or stage of development. Furthermore, splicing of the insulin receptor transcript is also regulated in a developmentally dependent manner [42, 81].

Mutations in the insulin receptor are correlated with insulin resistance syndromes of differing severity and are frequently associated with type 2 diabetes mellitus, hypertension, cardiovascular disorders, heart failure, metabolic syndrome and even infertility in women [152].

Health consequences of the insulin resistance are best represented by polycystic ovary syndrome (PCOS) or predisposition to breast cancer, colorectal carcinoma or pancreatic cancer $[1,16,28-30,33,41,44,47,55,56,79,89,90,96$, $102,103,115,116,121,124,156,163]$.

\section{In which way does insulin resistance predispose women to polycystic ovary syndrome?}

Almost 30 year ago, patients with extreme insulin resistance were shown to have enlarged and polycystic ovaries combined with hyperandrogenism of ovarian origin [62]. Recently, it has been stated that most common forms of insulin resistance are associated with enlarged ovaries [6, 97, 98, 108]. While metformin therapy can increase ovulation rate in patients with common forms of polycystic ovary syndrome (PCOS), recently the main focus in PCOS treatment has been the use of insulin receptor sensitizing drugs [29, 30, 41, 47, 90, 115, 156]. As insulin is 
a potential ovarian growth factor and stimulator of the androgen production, hyperinsulinemia is frequently observed in PCOS and is a common factor in extreme forms of insulin resistance syndromes. In contrast, gonadotropins stimulate normal ovarian growth during puberty as well as estrogenes and progesterone production. However, in the case of insulin resistance syndromes or in common forms of PCOS, the unique role of insulin as a stimulatory ovarian growth factor has not been clarified. While gonadotropins stimulate ovarian growth and steroidogenesis during puberty, hyperinsulinemia has been shown to stimulate pathological ovarian growth and androgenesis during the whole life [99]. Moreover, insulin stimulates the ovary independently from gonadotropins [6, 22, 62 ,97, 98, 108, 109]. Furthermore, in infants and small children suffering from leprechaunism, ovarian enlargement may be extreme in comparison to healthy infants with circulating gonadotropins, where it may be expected that the volume of ovaries is less than $1 \mathrm{~cm}^{3}[2,7,9,59,63,118,157]$.

While ovarian function has been partially restored (reduction in androgens secretion and recovery of menstruation) in older patients with lipodystrophy who were treated with leptin and in patients with insulin receptor auto-antibodies; no change in ovarian size was observed $[6,97,98]$. Hyperandrogenism in women with PCOS is often associated with a general increase of ovarian steroidogenesis, involving P450c17 $\alpha$ cytochrome activity which is a crucial enzyme involved in ovarian androgen biosynthesis. Hyperinsulinism either directly stimulates ovarian steroidogenesis through an increase in $\mathrm{P} 450 \mathrm{c} 17 \alpha$ activity or indirectly by stimulation of gonadotropins secretion [28, 102, 103]. Interestingly, in younger patients ovarian growth predominates the androgen increase, while in older patients both effects (ovarian growth and ovarian androgen over-secretion) are usually observed [98].

\section{Insulin resistance and neoplasia}

Metabolic syndrome refers to the relationship between insulin resistance, obesity and the risk of chronic disorders including cancer. While many of these associations remain unsolved, there is evidence to suggest that night lipolysis which is secondary to sympathetic stimulation, may not only lead to insulin resistance, but it may also be responsible for hyperinsulinism due to the stimulation of insulin secretion and a decrease in insulin clearance by the liver. Disorders generated in this way - an increase in night-time free fatty acids and insulin concentration - may synergistically lead to a higher risk of some types of cancer [55].

Obesity and insulin resistance are risk factors for the development of breast cancer and are often associated with late stages of the disease and with poor prognosis. Angiogenesis has been shown to be relevant to the development of breast cancer as it is likely that an increase in the production of some adipocytokines including VEGF, HGF, leptin, TNF $\alpha$, HBEGF and IL-6, in 
conjunction with a decrease in adiponectin which is known to suppress angiogenesis, enhances angiogenesis in obese individuals [116]. Obesity is also an independent risk factor for the development and progression of pancreatic carcinoma and in vivo studies revealed that the decreased levels of adiponectin combined with insulin resistance may directly lead to changes in a tumor's microenvironment, enhancing growth and metastasis of pancreatic carcinoma [163].

More than 50 mutations in insulin receptor gene, INSR, have been described. Such mutations are associated with rare forms of insulin resistance including leprechaunism, insulin resistance type A and Rabson-Mendenhall syndrome. Analysis of DNA and RNA from patients diagnosed with one of these syndromes has provided insights into the receptor's structure and function in the activation of downstream genes. These mutations were divided into 4 groups. Group 1 includes mutations that lead to a down-regulation of insulin receptor gene, while mutations that result in intracellular insulin receptor transport disorders and its maturation process (such as signal peptide cleavage or glycosylation) belong to group 2. Group 3 consists of mutations that are associated with insulin receptor binding defects and group 4 includes mutations that are characterized by disruptions in the catalytic activity of the tyrosine kinase domain.

The aim of the present work is to summarize the current knowledge on insulin receptor and its relationship with different forms of insulin resistance.

\section{INSULIN RECEPTOR GENE (INSR)}

The insulin receptor gene, INSR, (Gene ID: 3643) located on short arm of chromosome 19 (19p13.3), is $180 \mathrm{kbp}$ (kilobase pairs) long and consists of 22 exons (Fig. 1).

Most of the first exon encodes for 27 amino acid long signal peptide which directs the protein to plasma membrane. The first 11 exons of INSR gene encode the receptor's $\alpha$ subunit (this part of the gene spreads $90 \mathrm{kbp}$ ), while another other 11 exons encode the $\beta$ subunit and spreads approximately $30 \mathrm{kbp}[27,57,131$, 153]. Knowing the exon-intron INSR gene's structure enabled establishment of the functional and structural regions of the encoded protein. First exon encodes for signal peptide, the second one encodes for insulin binding region. Exon 3 encodes for cysteine-rich region and exons 4-10 encode for a major part of the receptor's $\alpha$ subunit. Exon 11 stands for alternatively spliced miniexon, while exons 12-14 encode for extracellular part of $\beta$ subunit. Exon 15 encodes for transmembrane domain and exon 16 encodes for juxtamembrane domain. Exons 17-21 with a little part of exon 22 encode for tyrosine kinase domain and the last one exon 22 encodes for a carboxyterminal part of the protein. In addition, the region spanning 


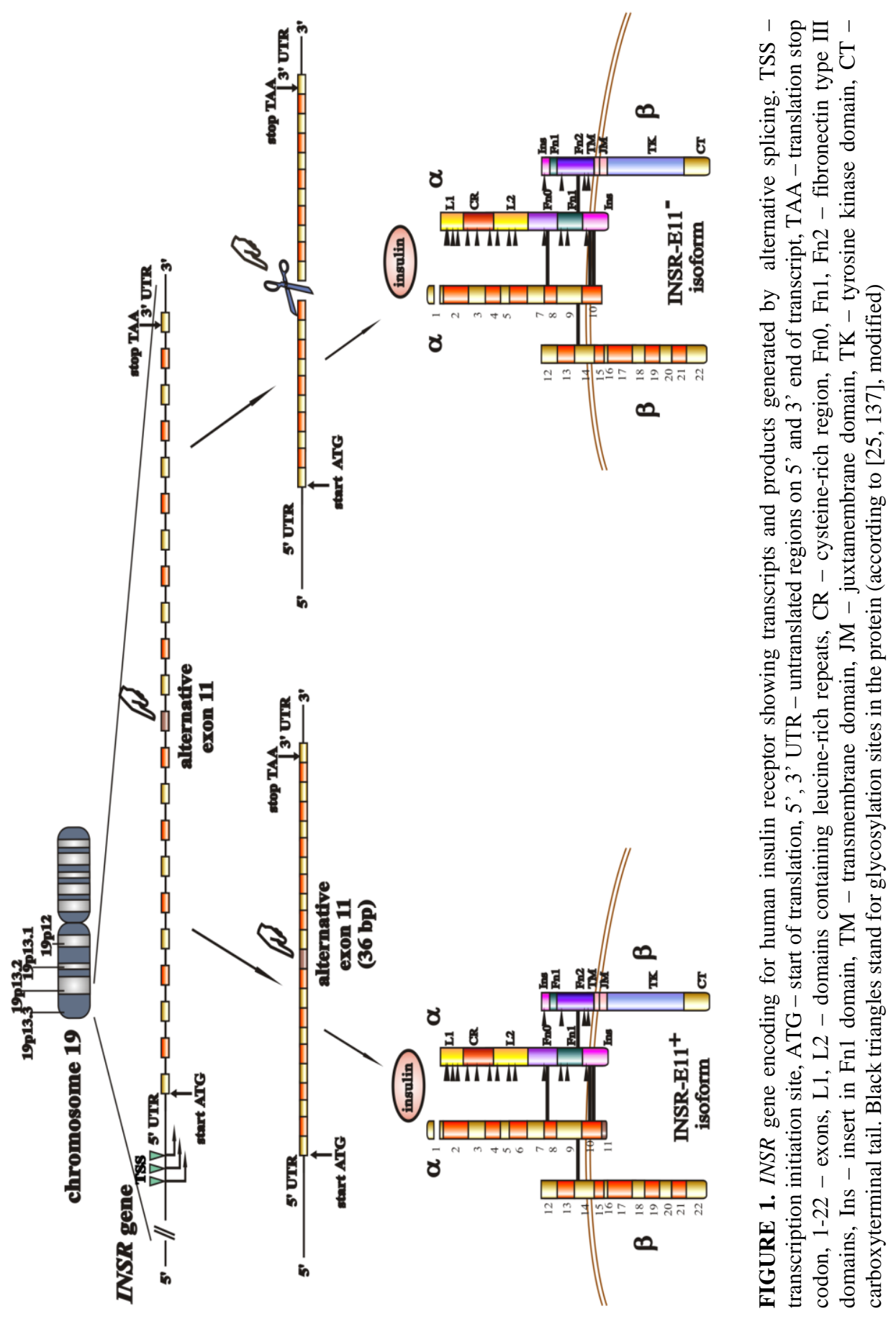


exons 2-5 has been shown to be homologous to a segment of the human epidermal growth factor (EGFR) gene [131].

Over 20 years ago the first several single nucleotide polymorphism (SNP) were found in INSR and included a range of silent mutations and missense mutations I421T (ATC-ACC) and Q465K (CAG-AAG) [131]. Subsequently, over 1820 SNP polymorphisms have been identified over the entire human INSR locus including the promoter region as well as 5' and 3' untranslated regions (UTRs) (http://www.ncbi.nlm.nih.gov/sites/entrez?db=snp\&cmd=search\&term=; 17.06.2009).

Interestingly, four of these polymorphisms have been clinically associated with different forms of insulin resistance. In 1988, Kadowaki et al. identified two different INSR alleles from a patient with leprechaunism. The maternal allele contained a missense mutation K460E (AAG-GAG) in exon 6, while a nonsense mutation D672X was identified in the paternal allele. As a result of these mutations, the protein encoded by this transcript lacked the transmembrane domain and the entire $\beta$ subunit [60].

The presence of the polymorphism N462S (AAT-AGT) also in exon 6 was identified in a patient diagnosed with insulin resistance and the skin disorder, Acanthosis nigricans [60].

In 1990, during the examination of family members, Moller et al. identified a polymorphism in exon 19 of the INSR gene. While the father suffered from hyperinsulinism (together with other abnormalities) and the mother was unaffected, their three daughters were diagnosed with insulin resistance type A (OMIM ID: 610549). Molecular studies revealed that the father and offspring carried an abnormal INSR allele that contained a dominant mutation A1134T (GCA-ACA) which disrupts the tyrosine kinase domains. Transfection analysis of $\mathrm{CHO}$ cells expressing mutant insulin receptors revealed that the mutation caused a decrease in the autophosphorylation of the receptor protein after binding its ligand, whereas the process of receptor maturation remained normal, as well as its ability to bind insulin [92].

Four years later, the heterozygous SNP polymorphism (CGG-CAG) in exon 20 of the INSR gene was found in 22 unrelated women, which suffered from insulin resistance, acanthosis nigricans and polycystic ovary syndrome (OMIM ID: 610549). The result of this SNP polymorphism was a R1174Q substitution in tyrosine kinase domain in the intracellular part of the receptor's $\beta$ subunit. As the mutation was present in patient's affected sister, and absent in her mother, presumably two affected parents' aunts were also carriers of this mutation, thus SNP polymorphism CGG-CAG (R1174Q) is considered to be the main cause of the dominant inherited insulin resistance [93]. 


\section{INSULIN RECEPTOR GENE PROMOTER REGION'S CHARACTERISTICS}

The INSR promoter region was first described in 1987 by Araki et al. [3] while subsequent characterization was undertaken by Seino et al. [131] (Fig. 2). Spanning approximately $1800 \mathrm{bp}$ upstream of the translation start codon bioinformatics analysis revealed that the promoter region is extremely GC rich. Interestingly, the promoter region lacks a TATA-box, which is present in most of genes transcribed by RNA polymerase II, as well as a CAAT-box. These characteristics are similar to the regulatory regions of housekeeping genes, which are expressed at steady levels including the human 3-phosphoglycerate kinase, human epidermal growth factor receptor, human hypoxanthine phosphoribosyltransferase, human adenosine deaminase, as well as hamster 3hydroxy-3-methylglutaryl coenzyme A reductase and murine hypoxanthine phosphoribosiltransferase [3]. In addition, a transcription enhancer element located 410-480 bp upstream start codon has been identified. Furthermore, several additional enhancer elements have been found within the promoter region that may bind $\mathrm{C} / \mathrm{EBP} \beta$ protein $(\mathrm{CAAT} / \mathrm{enhancer}$ binding protein $\beta$ ). Other DNA binding proteins elements were also found.

Additional features of the INSR promoter include seven potential Sp1 binding sites (GGGCGG or CCGCCC), two pairs of inverted CCGGGCCCG and CCCGGGCCGC repeats, which can be bound by transcription factors playing a role in the regulation of transcription initiation, three CCCGGGCGCAG and two CCGCCC direct repeats [3].

As the transcription factor, Sp1, enhances RNA polymerase II-directed transcription, it has been suggested that INSR transcript levels is modulated by $\mathrm{Sp} 1$ [3].

Further studies have discovered that the four GC-rich regions located at position -593 to -618 of the promoter, including Sp1 binding sites are the main elements regulating INSR expression in $\mathrm{CHO}$ and COS cells $[4,54]$. Interestingly, the $\mathrm{Sp} 1$ activation domain, located in the amino terminus, possesses two glutamine-rich domains $\mathrm{A}$ and $\mathrm{B}$ which are able to interact with RNA polymerase II transcription factor TFIID, consisting of TATA binding protein (TBP) and several TBP associated factors - TAFs. It has also been shown that TAFII-110 directly interacts with $\mathrm{Sp} 1$ [54].

Furthermore, it was noted that there are IRNF-I and IRNF-II (Insulin Receptor Nuclear Factor) binding sites located at positions -530 to -550 and -500 to -520 of the INSR gene promoter region. It was shown that mutations which alter these binding sites strongly down-regulate insulin receptor gene expression. This shows that both factors are necessary for its proper expression pattern [76]. Interestingly, adenoviral E1a protein may also bind to Sp1 factor bindin sites within the promoter region and thus regulate INSR gene expression [66]. 

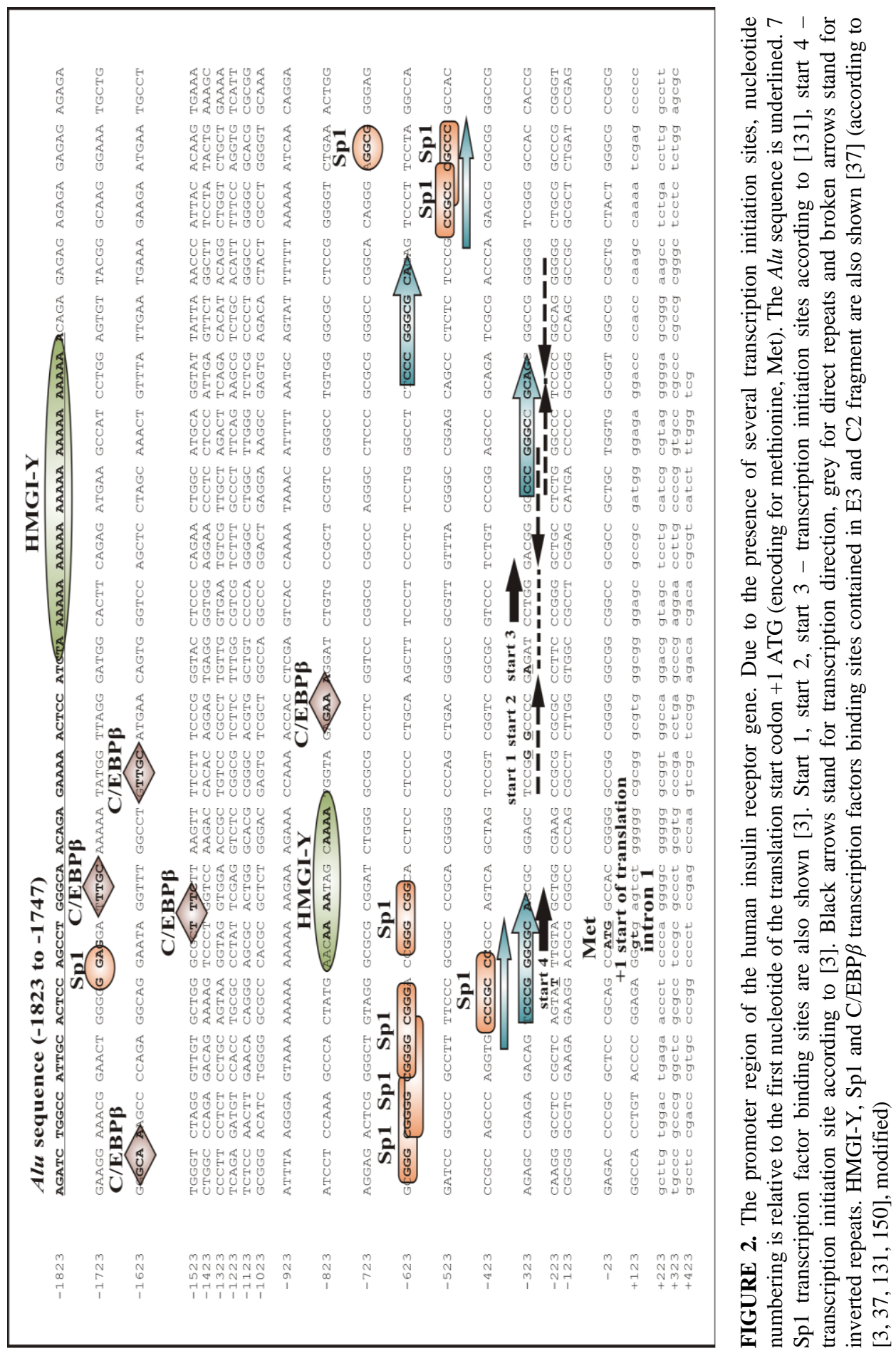
Using primer extension and nuclease S1 mapping/ nuclease S1 protection assays, three transcription initiation sites at positions 276, 282 and 283 bp upstream the ATG codon have been identified, with the most abundant transcripts starting at positions 276 and 282 [32]. Similar features such as inter alia lack of TATA-box and a presence of several transcription initiation sites, are a characteristic feature of promoters regions of many housekeeping genes [58, 67, 139].

It was observed that INSR gene is up-regulated by glucocorticoids [84]. While it has been suggested that these hormones may lead to the induction of INSR gene transcription, analysis of the 5' promoter region failed to reveal the presence of the glucocorticoid response elements (GREs) [64]. In turn, Rubin et al. identified Alu sequence in the 5' end of the INSR promoter, which is thought to play a role in protein binding and may thus potentially regulate insulin receptor gene expression [119]. Several potential regulatory promoter regions have also been identified which are important for cell-specific receptor protein expression $[12,14,145]$. DNase I footprinting analysis revealed that two AT-rich regions, which were named as $\mathrm{C} 2$ and E3 fragment located at positions: -671 to -874 and 1661 to -1818 , respectively, are essential for INSR gene expression during differentiation of myoblasts into myocytes in $\mathrm{BC} 3 \mathrm{H}-1$ muscle cells [13]. Interestingly, a chloramphenicol acetylotransferase reporter gene assay revealed that these sequences acted rather as promoters than transcription enhancer elements. Accordingly Brunetti et al. suggested that the proteins binding to these regions play a crucial role in the spatial expression of ISNR [13]. Further experiments revealed that these regions (C2 and E3) are bound by high mobility group proteins (HMGI-Ys), in this way activating INSR gene transcription [15]. Electrophoretic mobility shift assay (EMSA) and Western blot experiments using nuclear proteins isolated from human lymphocyte IM-9 cell line enabled identification of the protein, which was named IR-DBP (Insulin Receptor DNA Binding Protein) and was highly similar to HMGI-Y proteins. While IR-DBP protein is a distant member of HMG protein family, it is able to bind and bend the minor groove of double-stranded DNA helix, leading to the changes in local DNA conformation. Through interactions with numerous transcription factors, IR-DBP may activate gene transcription [20, 112]. It was observed that the HMGI-Y inhibition in cells up-regulating INSR, led to its down-regulation. In turn, HMGI-Y over-expression in cells down-regulating the INSR, led to its up-regulation [15]. Taken together, it has been suggested that HMGI-Y positively regulates the expression of INSR. Accordingly, mutations affected HMGI-Y may contribute to abnormal function of the insulin receptor and subsequently to the disorders in insulin signal transduction pathway.

It was also observed that $278 \mathrm{bp}$ long region located in the 5 ' end of the first intron of INSR is essential for expression in HIRIN3 adipocytes [85].

In 2001 Youshizato et al. identified a cis- regulatory element (-592 to -577) and trans-acting factor which influenced the expression of INSR in hepatocarcinoma HepG2 cells and in rat hepatocytes. Subsequent analysis revealed 
that characterized the $35 \mathrm{kDa}$ trans-acting nuclear protein, HT-FIR factor (Hepatocyte-specific Transcription Factor of the Insulin Receptor gene) could bind a 5'-TCCCTCCC-3' sequence located within this promoter region (position -588 to $-581)$.

Although the insulin receptor gene promoter activity is associated with a region located approximately $579 \mathrm{bp}$ upstream the translation initiation codon, it is suggested that the whole promoter region is necessary for its maximal activity [14].

While basal promoter activity is observed in all cells, up-regulation of INSR was observed in skeletal muscles, the liver, adipose tissue or the brain. This may suggest the existence of tissue-specific factors regulating INSR expression, whereas differences in the level of gene expression in different tissues may result from the presence or absence of tissue-specific transcription factors. It is known that promoters of many genes which are tissue-specifically expressed are frequently under the control tissue specific and general transcription factors [88].

In 2003, Foti et al. [37] uncovered that the regulation of INSR is dependent on the formation of a nucleoprotein complex (called enhanceosome) which in HepG2 cells is composed of HMGI-Y and general transcription factors . Foti et al. also showed that HMGI-Y played an essential role in this complex and was necessary for the assembly of an active transcription initiation complex [37]. Additional in vitro and in vivo experiments also revealed that the interactions between HMGI-Y, Sp1 and C/EBP $\beta$ significantly increased the insulin receptor gene promoter region activity and activated RNA polymerase II-directed transcription [37]. Consequently, any defects of transcription factors described above may influence the insulin receptor gene expression and thereby a lack of response on insulin.

\section{INSULIN RECEPTOR TRANSCRIPT'S CHARACTERISTICS}

INSR was first identified in 1971 by Freycht et al. [39] and the cDNA sequence relevant to the INSR gene transcript sequence was established independently by Ullrich et al. [153] and Ebina et al. [27] in 1985.

Surprisingly, the research groups obtained sequences that differed in length by 36 nucleotides. Bioinformatic analysis of these sequences revealed that the insulin receptor transcript undergoes alternative splicing, in which exon 11 (encoding the carboxyterminal end of the $\alpha$ subunit) is occasionally skipped. This splicing event (exon exclusion/exon skipping) results in the formation of a shortened transcript called the 'short variant' (or second variant, E11', A) as opposed to the unspliced transcript or the 'long variant' (or the first one, E11 ${ }^{+}, \mathrm{B}$ ) that contains exon 11 (36 bp long, corresponding to the 717-728 amino acid residues) . These two isoforms encode for proteins of 1370 and 1382 amino acids 
respectively [27, 153] (Fig. 1). Alternative splicing is a tissue-specific process and has been shown to alter the receptor ability to bind insulin. Experiments using transfected cell lines has revealed that there are differences in the internalization of different forms of the receptor induced by insulin binding [48]. There are also studies which suggest that the short form is expressed in leukocytes, and the longer form dominates in the liver, adipocytes and skeletal muscles, while in the placenta the level of both forms remains similar. Interestingly, the insulin binding affinity of the short variant is twice as much as the long variant E11 ${ }^{+}$[91]. Some of the studies noted that the shorter protein form is characterized by an increased rate of internalization process after ligand binding, whereas the longer protein with lower insulin binding affinity has higher catalytic activity in comparison to it shorter isoform [48]. It was also found that the isoform without the protein part encoded by exon 11 may bind insulin as well as IGF-II with high affinity, while the other isoform can bind only insulin [91].

While the biological significance of the two alternative spliced transcripts is yet to be established, it may be possible that disorders with alternative INSR transcript assembly leading to changes in both forms ratio in different tissues may lead to the development of various severe diseases in human $[65,70,95,104,106$, 126], though, the differences in both insulin receptor mRNA expression level has not been observed yet in patients suffering from various forms of insulin resistance in comparison to healthy ones [130].

The overall length of INSR transcript differs depending not only on the presence of several transcription initiation sites, but also a number of polyadenylation sites. Transcripts ranging from 5400 to 9400 bp have been observed, the most abundant are 6,900 bp and 9,400 bp long [150]. Interestingly, though, the small protein size, transcript length is significant and depends on the considerably 3'UTR length (4801 bp) what is similar to transcripts isolated from other organisms such as $e$.g. rat [150]. It is possible, that this region may play some regulatory functions. It has also been suggested that some of the posttranscriptional mechanisms may also be implied in the control of INSR mRNA as well as a sole protein expression. Alternative splicing mechanism remains under control of insulin as well as other factors. Disorders of this process may lead to higher insulin sensitivity, what suggests that the regulation of insulin receptor mRNA alternative assembly is crucial for insulin receptor sensitivity and the cell response [71]. In the alternative splicing sites selection there are numerous proteins and additional factors involved, including RNA secondary structure $[8,32,142$, 143], exon length and the "strength" of alternative splicing sites [101]. While changes in these sites selection have been frequently observed in genes during cell differentiation [86], hormonal regulation is not common. For instance, glucocorticoids have been shown to modulate insulin receptor mRNA alternative splicing in HepG2 cells, while insulin has been shown to modulate the same mechanism in hepatocarcinoma $\mathrm{FaO}$ cells [70, 132]. Studies conducted by Kadowaki et al. identifed sites important for alternative INSR transcript splicing. 
Exon 11 is very short (36 bp) and is flanked by long introns ( 2,2 kb and $\sim 7,5 \mathrm{~kb})$. It was shown that intron 10 of the insulin receptor gene contains all the elements necessary for the proper splicing site selection and alternative exon 11 exclusion. There are two branch point (BP) sites in this intron which are crucial for splicing site selection. $300 \mathrm{bp}$ upstream exon 11 there is an Alu sequence. 43 bp upstream the branch point in intron 10, there is an intronic splicing enhancer sequence (ISE) as well as intronic splicing silencing sequence (ISS) located at its 3' end responsible for exon skipping. ISE sequence located at 5' end of intron 10 contains a GA-rich sequence 48 bp long, crucial for exon 11 inclusion in the mature mRNA molecule [72].

The splicing site selection model during the insulin receptor transcript maturation was proposed in 1998 [72]. According to this model, the GA-rich sequence located on the 5' end of the intron 10 otherwise known as the intronic splicing enhancer sequence ISE, favours exon 11 inclusion in the mature transcript by direct interaction with 3' splicing site. It is possible that due to its location (more than $2 \mathrm{~kb}$ upstream branch point, BP), this region may interact with an adjacent 5' splice site (UAG:GUCAGGAC) considerably different from a consensus sequence (CAG:GUAAGUAU) [72]. Thus, the role of this enhancer may rely on the strengthening the interaction of U1snRNP (U-rich 1 small nuclear ribonucleoprotein particle) - one of the component of the spliceosome, with 5' splicing site [74]. However, the effect on the alternative splicing of the downstream exon, remains unknown. Furthermore, it has been suggested that the SF2/ASF protein is able to bind to GA-rich sequences which are similar to those present on the 5'end of intron 10. Accordingly, SF2/ASF protein may promote exon 11 retention in the INSR mature transcript, in similar way to splicing of the rat clatrine light B chain [21]. SF2/ASF protein may also preferentially use of proximal 5' or 3' splicing site. In turn, hnRNP-A1 splicing factor (which binds to UAGGGA or UAGGGU sequence) acts antagonistically, promoting distal splicing site selection. Thus, both factors act in an antagonistic way [19]. At the 5' end of intron 10 there is an additional CTTAGGGACC sequence, containing hnRNP-A1 binding site (underlined). It is already known that this nucleoprotein together with hnRNP-F is involved in the regulation of INSR transcript alternative splicing [148]. At the 3' end of intron 10 there are two regions located, which also play a role in INSR transcript alternative splicing. One of them, located upstream the branch point, promotes exon 11 exclusion from mRNA and is called intronic splicing sequence silencer (ISS). Furthermore, bioinformatic analysis has showed that this region may form a secondary stem-loop structure that plays a role in alternative splicing of mRNA. The second regulatory region, important for alternative splicing of INSR transcript is located in exon 11 and seems to act independently in the modulation process of 3' splice site selection. It can't be excluded that both regions are components of a larger secondary structure around the 3' splice site [72].

The function of intronic and exonic splicing sequence enhancers (ISE, ESE) and silencers (ISS, ESS) in alternative splicing regulation, relies on relevant 
trans-acting factor binding, which in turn, influence splicing site selection by spliceosome [11]. Secondary structure of the premature transcript regulates availability of splicing factors. Such double-stranded stem-loop RNA structures are recognized by trans-acting factors and the whole complex lead to changes in mutual spatial distribution of $c i s$-acting elements in this way forming additional regulatory "possibilities" $[18,45,53]$. Further studies investigating the alternative splicing of the insulin receptor has led to the identification of ISE and ISS elements in intron 10, as well as to better understanding of its mechanism [133, 158]. In addition, SRp20 and SF2/ASF have been shown to modulate exonic enhancer elements (ESE) activity. Moreover, it was shown, that ESS elements in exon 11 and ISS elements at the 3' end of intron 10 need CUG-BP1 protein binding. CUGBP1 protein overexpression promoted exon 11 exclusion in INSR transcript, while SRp20 overexpression led to the enhancement of exon 11 retention [133]. Sen et al. consequently suggested that both proteins would act antagonistically and their mutual balance is crucial for regulation of exon 11 inclusion or elimination from transcript [133]. Schematic representation of the proposed mechanism for the alternative splicing of the insulin receptor mRNA is depicted in Figure 3.

Although the function of SRp20 and SF2/ASF has not been completely resolved, it has been postulated that these proteins lead to the recruitment of U1 and U2 snRNPs or prevent from CUG-BP1 proteins binding. It is possible that the activity of these factors may also be regulated by each other. It is still proposed that exon 11 together with an upstream polypyrimidine tract and a sequence containing branch point BP, form a large secondary stem-loop type structure, which occurrence inhibits U2AF, SF1 and U2 snRNP binding and, in this way, blocks 3' splice site availability. The ability of a secondary RNA structure to inhibit splicing was shown in studies that characterized splicing of SMN2 (Survival Motor Neuron 2) gene, one of genes associated with spinal muscles atrophy [140]. The overlapping SF2/ASF and CUG-BP1 protein binding sites in exon 11 are located in a secondary RNA structure, upstream of which there is a SRp20 protein binding site. It is assumed that SRp20 and SF2/ASF binding prevent the formation of a secondary RNA stem-loop type structure. In turn, CUG-BP1 binds to its binding site and to the silencer sequence and stabilizes a double-stranded stem-loop fragment that aid in exon 11 being spliced out [133]. In order to confirm this hypothesis, molecular studies are currently being conducted at the University of California. 


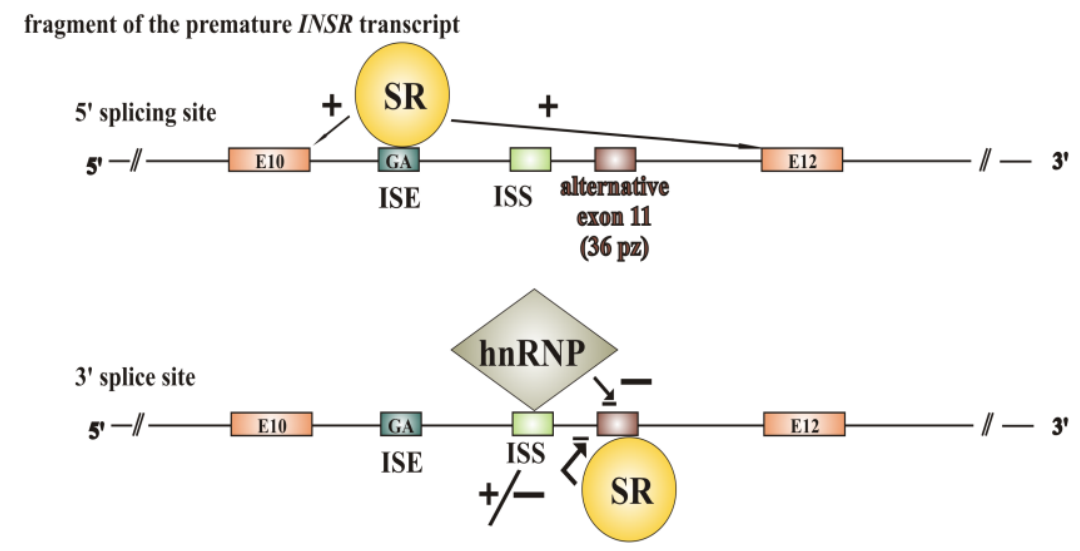

secondary RNA structure

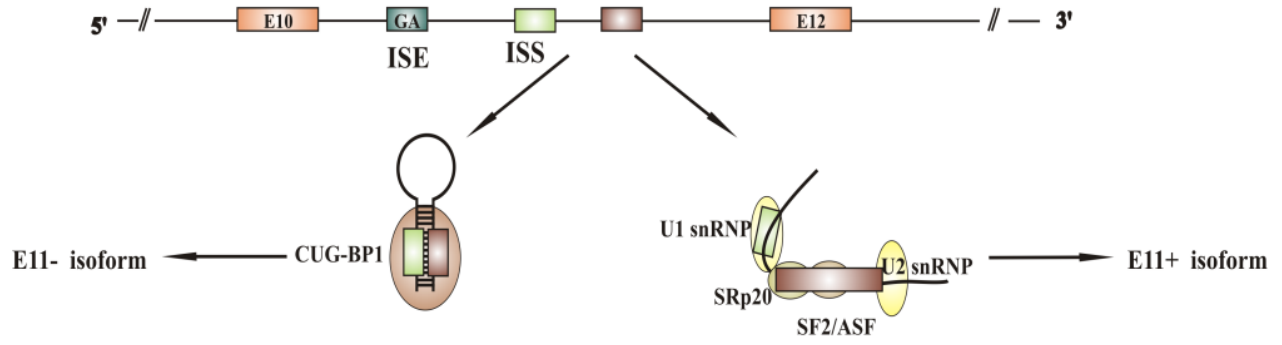

FIGURE 3. Proposed model for human insulin receptor transcripts alternative splicing regulation. In the alternative splicing sites selection numerous proteins and additional factors are involved, including RNA secondary structure, exon length and the "strength" of alternative splicing sites. Intron 10 of the INSR gene contains all the elements necessary for the proper splicing site selection and alternative exon 11 exclusion. There are two branch point (BP) sites in this intron which are crucial for splicing site selection. $43 \mathrm{bp}$ upstream the branch point in intron 10, there is an intronic splicing enhancer sequence (ISE) and intronic splicing silencing sequence (ISS) located at its 3' end responsible for exon skipping. GA-rich ISE sequence located at 5' end of intron 10 favours exon 11 inclusion in the mature transcript by direct interaction with 3' splicing site. It is possible that due to its location, this region may interact with an adjacent 5 ' splice site. Its role may rely on the strengthening the interaction of U1snRNP (U-rich 1 small nuclear ribonucleoprotein particle) - one of the component of the spliceosome, with 5' splicing site. It has also been suggested that the SF2/ASF protein is able to bind to GA-rich sequences which are similar to those present on the 5'end of intron 10. Accordingly, SF2/ASF protein may promote exon 11 retention in the INSR mature transcript (upper panel). In turn, hnRNP-A1 splicing factor acts antagonistically, promoting distal splicing site selection (middle panel). Intronic splicing sequence silencer (ISS) may form a secondary stem-loop structure (lower panel) that plays a role in alternative splicing of mRNA. The second regulatory region is located in exon 11 and seems to act independently in the modulation process of 3' splice site selection. ESS elements in exon 11 and ISS elements at the 3 ' end of intron 10 bind CUG-BP1 protein binding and promote exon 11 exclusion. In turn, SRp20 and SF2/ASF favour exon 11 retention in INSR transcript by leading to the recruitment of U1 and U2 snRNPs or preventing from CUG-BP1 proteins binding (according to [72, 133], modified) 


\section{HUMAN INSULIN RECEPTOR'S STRUCTURE}

The mature insulin receptor is a glycoprotein that functions as a heterotetramer consisting of two dimers of two subunits (each 1370 or 1382 aminoacid residues long) connected by 14 disulfide bridges. This receptor is synthesized inside the cell as a premature proreceptor precursor $(\mathrm{Mr} \sim 180 \mathrm{kDa})$ which undergoes proteolytic cleavage within a Arg-Lys-Arg-Arg sequence located at the connection of $\alpha$ and $\beta$ subunits releasing, in this way, $\alpha-\beta$ monomers. The $\alpha-\beta$ connection is possible due to the existence of disulfide bonds formed between cysteine 647 of $\alpha$ subunit and cysteine 872 of $\beta$ subunit. Two $\alpha-\beta$ monomers are subsequently connected by Cys-524 bonds between $\alpha$ subunits [73].

The $\alpha$ subunit $(\mathrm{Mr}=135 \mathrm{kDa})$ is an extracellular domain which can bind insulin, while the $\beta$ subunit ( $\mathrm{Mr}=95 \mathrm{kDa}$, consisting of 620 amino-acid residues) posses a 194 amino-acid extracellular region a 23 -amino-acid long transmembrane region and a 403-amino-acid long intracellular tyrosine kinase domain [27, 57, 131, 153]. In addition, the $\alpha$ subunit, as well as an extracellular region of the $\beta$ subunit have several glycosylation sites [131].

Following the signal peptide, in aminoacid sequence, there is a L1 domain containing leucine-rich repeats (52-164 residues) which serves for an insulin binding site, a cysteine-rich region CR (179-340 residues) and a furin-like and a FU region (234-281 residues) containing furin-like repeats. The next region, the L2 domain (359-472 residues), is located upstream of three fibronectin type $3 \mathrm{Fn}$, Fn1, Fn2 domains (Fig. 1). The aminoterminal end of the protein (encoded by exons 1-2) as well as cysteine-rich domains (encoded by exons 3-5) together with carboxyterminal end consisting of 704-719 residues are responsible for insulin binding with high affinity [73], and the presence of the 12-aminoacid long sequence encoded by alternative exon 11 modulates the ligand binding affinity. Several key residues of the receptor include positions 906 and 920 that are crucial for inter-domain contact. Other residues such as 921-922 and 924-925 stand for cytokine receptor motif that is followed by catalytic tyrosine kinase domain. Formed by the following residues: 1020-1021, 1025, 1043, 1045, 1092, 1094, 1098, 1151-1152, 1154, 1165 (Gly-X-Gly-X-X-Gly), the ATP-binding site is located in $\beta$ subunit [125]. Two tyrosine residues (Tyr-965 and Tyr-972) located in the juxtamembrane JM domain of $\beta$ subunit undergo autophosphorylation after insulin binding. Another phosphorylation site is located in the centre of the intracellular domain (within the following sequence: Tyr-1158-X-X-X-Tyr-1162Tyr-1163), and two others are located on the carboxyterminal end of the protein (inside CT domain) (Tyr-1328 and Tyr-1334) [125]. Tyrosine 972 phosphorylation leads to the NPXpX motif formation, recognized by PTB domain of IRS-1 and Shc proteins. This NPXpX motif is also important for receptor internalization process [160]. In turn, it was shown that the autophosphorylation of the tyrosine residues present in a regulatory kinase domain is crucial for catalytic activity of the receptor 
induced by insulin and insulin biological effect. In addition, the activated KRLB (Kinase Regulatory Loop Binding) domain is necessary for interactions between a unique region of IRS-2 protein spanning 591-768 residues and insulin receptor [125]. In turn, residues 1034-1037, 1115, 1117, 1157-1158, 1283 and 1288 form a non-catalytic PTP1B binding site, and amino acids at positions: 1151, 1180, 11821184, 1186-1187, 1196-1197, 1199, 1230 are a substrate protein binding site. The activating loop (A-loop) is located at positions 1164-1185 while residues at positions: 1171, 1173-1174, 1176-1177 are involved in a formation of interaction site with SH2 domains of the target proteins.

Insulin binding with $\alpha$ subunit is suggested to bring both subunits into close proximity. This enables the $\beta$ subunit to bind ATP which triggers a phosphorylation cascade. Phosphorylation and activation of the IRS (insulin receptor substrate) proteins: IRS-1 and IRS-2, lead to binding and activation of other proteins containing SH2 ( $\mathrm{Src}$ homology 2) domains such as Shc and adaptor APS proteins [149]. Activation of these proteins releases a subsequent cellular signaling cascade which leads to the accumulation of cellular effectors and insulin signal transduction process inside the cell.

Regulation of glucose transport into the cells as well as several other metabolic process are under the control of phosphatidylinositol 3-kinase. Its p85 regulatory subunit binds to the phosphorylated tyrosine residues of IRS-1 protein leading to its conformational change and activation of catalytic p110 subunit of IRS-1 protein. Subsequently, the whole enzyme transits to the cell plasma membrane. Phosphatidylinositol 3-kinase catalyzes phosphatidylinositol 4,5bisphosphate phosphorylation to phosphatidylinositol 3,4,5-triphosphate which is involved in the protein B kinase (PKB) activation process, also named AKT kinase. Direct interaction of the PIP3 molecule with PH domain of the AKT kinase leads to its transfer to the plasma membrane, where it undergoes activation by phosphatidylinositol PDK-1 kinase. AKT kinase, in turn, is responsible for the phosphorylation of various cellular proteins involved in various metabolic pathways and pathways that regulate cellular growth and differentiation [1,33]. This enzyme, by inhibiting GSK-3 kinase, also enhances glycogen synthesis, and by regulating mTOR (mammalian target of rapamycin) kinase induces synthesis of various cellular proteins. AKT kinase is also responsible for "cell survival" by blocking several proapoptotic factors including Forkhead family transcription factors. The PI3K/AKT kinase signaling pathway also involves translocation of a membrane glucose transporter GLUT4, which transport glucose molecules to the cells' interior. Mitogenic effects of insulin action are caused, by not only AKT kinase pathway activation, but Ras/MAPK kinase as well [43, 77, 159].

Phosphorylated and activated Shc binds to the Grb2/SOCS complex (growth factor receptor-binding protein 2). Relocation of SOCS protein to plasma membrane enables its interaction with Raf kinase anchored to the plasma membrane and its activation. Subsequently, activated Ras, activates Raf kinase, and this leads to the activation of MAP and ERK kinases phosphorylation cascade [44, 
$69,127,155]$. In the next step of signaling pathway, ERK kinases are translocated to the nucleus and activate transcription factors such as c-jun, c-fos and c-myc. Consequently, the response to insulin also involves the induction of genes' expression which are involved in the proliferation processes $[46,69,146]$.

After insulin signal transduction inisde the cell, insulin receptor undergo internalization process. Some of the receptors are directed back to the plasma membrane in clatrin-coated vesicles, while others are degraded in lysosomes [3, 122].

Tissue-specific alternative splicing of the insulin receptor transcript leads to the formation of two, fully functional forms of the receptor and the ratio of them differs depending on tissue.

Precursor receptor protein maturation occurs in the endoplasmic reticulum (ER) . The INSR precursor is subsequently proteolytically cleaved in trans Golgi to form the mature INSR protein which is then transported to the cell's surface [122]. The growing polypeptide chain of the insulin receptor translocates through the Sec61 translocon to the endoplasmic reticulum lumen [5]. In the meantime, Glc3Man9GlcNAc2 oligosaccharide core is co-translationally added to the protein in $\mathrm{N}$-glycosylation process by oligosaccharide transferase. This core is subsequently shortened by the activity of glucosydase I and II $[31,52,120]$. The next step in the insulin receptor maturation process, is thought to involve the two ER lumenal proteins calnexin and calreticulin. Acting as a quality control system for improperly folded proteins, it has been suggested that calnexin and calreticulin aid in the addition of carbohydrate substrates and oligosacharide shortening. Misfolded glycoproteins are directed by retrograde transport from the endoplasmic reticulum lumen back to the cytoplasm where they undergoe ubiquitin-dependent proteolytic degradation by the 26S proteasome [5]. Cytoplasmic HSP90 as well as glucose-regulated protein Grp94 (Mr=94 kDa), a HSP90 homologue residing in the lumen of ER, are both involved in protein maturation. These protein ensures the proper maturation of other proteins and signal transducers translocation such as steroid hormones, growth factor receptors and others [17].

\section{INSULIN RECEPTOR ISOFORMS AND INSR/IGF-1R HYBRID RECEPTORS}

As mentioned above, there are two insulin receptor isoforms, which differ

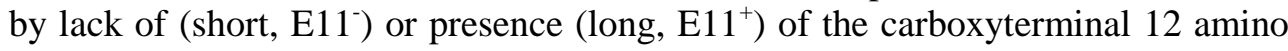
acid long fragment located at the end of $\alpha$ subunit and encoded by alternatively spliced transcripts $[27,153]$.

It is believed that these two insulin receptor forms are immunologically and functionally distinct $[83,94,123,134-136,154,161,162]$. In 1988, Sakata et al. suggested that the carboxyterminal domain of $\alpha$ subunit of the E $11^{+}$receptor 
isoform, relative to 705-731 amino-acids is the main auto-antigenic site [123]. In turn, Sesti et al. revealed that the IgG fraction, isolated from patients suffering from autoimmune hypoglycemia (autoantibodies against insulin receptor) inhibited insulin binding by receptors expressed in cells transfected with vectors and overexpressing E11 ${ }^{-}$form, but there was no effect on insulin binding in cells transfected with vectors and overexpressing E11 ${ }^{+}$form [134]. Two years later it was demonstrated that an antibody directed against the amino terminal region encoded by exon 11, was able to inhibit insulin binding by E11 ${ }^{+}$, but not by E11 form [135]. Furthermore, other studies have shown that the two insulin receptor isoforms have different ligand with the E11 ${ }^{-}$variant binding insulin twice as much as a protein encoded by transcript with exon 11 [94, 161, 162].

The differing ligand affinity may reflect changes in insulin acting as a metabolic or mitogenic factor [83]. Moreover, it seems that E11 isoform is characterized by a higher rate of internalization and recycling in the cell $[154,161]$. In some cases, experiments using transfected mammalian cells expressing separately two receptor isoforms revealed down-regulation of insulin-induced E11 form [162]. Frasca et al. [38] found that the E11 isoform may bind insulin-like growth factor II (IGF-2). Interestingly, IGF-2 binds to the E11' receptor with quite high affinity (approximately $40 \%$ of value observed for insulin), but it is not able to bind to the E11 $1^{+}$receptor. Furthermore, IGF-2 binding by insulin receptor was shown to have a mitogenic rather than metabolic effect inside the cell [38].

As mentioned earlier, the two isoforms are differentially expressed in a cell-, tissue- and developmentally-specific manner [38, 91, 130, 135, 136]. While both isoforms are expressed in placenta, kidneys, adipose tissue and skeletal muscles, the short variant is expressed in hematopoietic and nervous cells and $\mathrm{E} 11^{+}$ isoform dominates in liver [91, 130, 135, 136]. Furthermore the short form of the receptor is expressed mainly in fetal tissues such as kidneys, skeletal muscles, liver and fibroblasts [38].

Cellular differentiation also influences the expression of both transcripts. For instance, in colorectal carcinoma and breast cancer, E11 ${ }^{-}$is the dominant form of the insulin receptor and there is thus an increase in regulatory possibilities of the cell's growth by IGF-2 [38, 128].

In vivo [104] and in vitro [105] studies conducted by Norgren et al. revealed that alternative splicing of the insulin receptor transcript may be regulated hormonally and metabolically.

The short 12 amino-acid long sequence encoded by exon 11 has been shown to modulate the receptor's affinity for insulin, by potentially forming the relevant binding site with other regions of the receptor. It can't be excluded that the presence of this region may influence other function of this extremely important protein in the cell. Whereas the insulin receptor occurs in two alternative splicing forms $\mathrm{E} 11^{+}$and $\mathrm{E} 11^{-}$, insulin-like growth factor 1 receptor IGF-1R occurs only as a "E11" form [82, 87]. Both the INSR and IGF-I receptors belong to the subclass II of tyrosine kinases, which have a high sequence and function homology [27, 153]. 


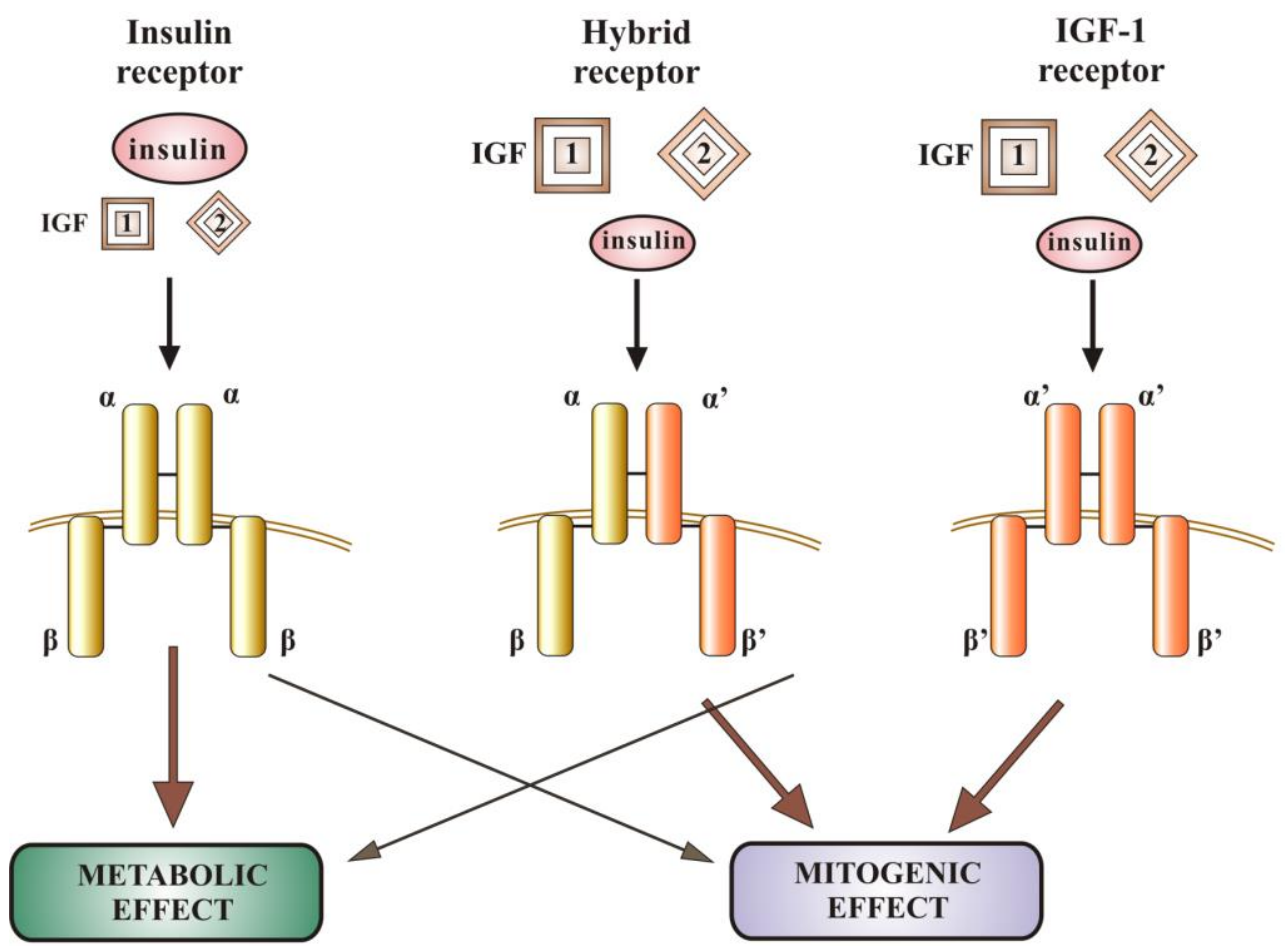

FIGURE 4. Insulin receptor, IGF-1 receptor and hybrid receptor INSR/IGF-1R together with bound ligands and metabolic or mitogenic effects caused within the cell. Both INSR and IGF-1R receptor have low affinity to the homologous hormone. Insulin receptor binds mainly insulin leading to the metabolic effect. In turn, IGF-1R receptor binds IGF-1 and IGF-2 with higher affinity in comparison to the insulin and thus lead to the mitogenic rather than metabolic effect. The hybrid receptor formed by dimerization of two different subunits of the INSR and IGF-1R receptor can bind IGF-1 and IGF-2 with high affinity, while the affinity of such hybrids to insulin is lower than the insulin receptors. Thus binding insulin-like growth factors lead to mitogenic rather than metabolic effects within the cell (according to [23, 24, 137], modified)

In contrast to other tyrosine kinases which dimerize after binding to their ligands, both INSR and IGF-1R receptors are present in cell membrane as already formed dimers of $\beta-\alpha-\alpha-\beta$ structure. Proreceptors dimerization takes place in endoplasmic reticulum, where disulfide bridges are formed, stabilizing the whole structure of the receptor, before proteolytic cleavage into $\alpha$ and $\beta$ subunits [107].

Insulin plays a role in the regulation of glucose concentration, lipid metabolism in muscles, liver and adipose tissue, whereas IGF-1 stands for growth factor for most of the cells "Cross-reaction" studies revealed, that both receptors have low affinity to the homologous hormone (INSR to IGF-1 and IGF1-R to insulin), thus it is suggested that at physiological condition these receptors should response only in the presence of its own ligand. In certain conditions however, insulin may play a role as a growth regulator, and IGF-1 may lead to metabolic 
effects similar to those evoked by insulin action. Furthermore, most of the disulfide bridges in the $\alpha$ subunits are also conserved. It has accordingly been suggested that a hybrid INSR/IGF-1R receptor may form and be composed of $\alpha / \beta$ insulin receptor heterodimers and $\alpha / \beta$ IGF-1R receptor heterodimers (Fig. 4) [10].

Surprisingly, it was shown that the hybrid receptor binds IGF-2 with similar affinity to IGF-2 receptors, while the affinity of such hybrids to insulin is lower than the insulin receptors $[75,144]$. In addition, these hybrid receptors resemble the IGF-2 receptors rather than the insulin receptors when it comes to protein autophosphorylation, internalization and degradation [129]. Hybrid distribution differs depending on tissue; for instance a significant percentage of such receptors have been seen in human tissues such as placenta, skeletal muscles, adipose tissue, erythrocytes, leukocytes and fibroblasts [34]. While the factors regulating hybrid receptors formation in vivo have not been defined yet, it has been proposed that they may form by chance with the same efficiency and in ratio determined by molar concentration of the defined forms. As insulin and IGF-1 regulate expression of its own receptors' genes, changes resulting from insulin and/or IGF-1 receptors number induced by these hormones may also modify the number of hybrid receptors. In skeletal muscles of patients with insulinoma and hyperinsulinism, it was observed that the number of hybrid receptors was elevated, what markedly correlated with higher insulin level in blood and smaller number of insulin receptors [35]. Other studies showed an up-regulation of hybrid receptors in skeletal muscles in obese patients with high fasting insulin level and lower IGF-1 level in blood. The ratio of hybrid receptors correlated with a down-regulation of insulin receptors and an up-regulation of IGF-1 receptors [36]. These observations suggest that changes in insulin level contribute to insulin receptor down-regulation, IGF-1 receptors up-regulation and up-regulation of hybrid receptors. Mixed receptors can bind IGF-1 with a high affinity, thus they may be activated in physiological conditions by IGF-1 rather than by insulin leading to mitogenic rather than metabolic effects (Fig. 4).

\section{INSULIN RECEPTOR DEFECT AS A CAUSE OF RARE SYNDROMES}

Insulin resistance is one of the most frequently observed disorders associated with defects in hormonal regulation and is a main cause of hyperglycemia in patients with diabetes mellitus type 2. Furthermore, insulin resistance is commonly related to insulin action defects downstream the insulin receptor [100]. Surprisingly, insulin resistance connected with defects in the function of the insulin receptor function are rare (Table 1). 
TABLE 1. Characteristic features of genetic disorders associated with severe forms of insulin resistance $[2,6,7,22,26,40,49,51,59,61,62,68,78,80,97,110,111,113,114,117,138,141$, $147,152]$.

\begin{tabular}{|c|c|c|}
\hline SYNDROME & CLINICAL FEATURES & MOLECULAR MECHANISM \\
\hline $\begin{array}{c}\text { Insulin } \\
\text { resistance type A }\end{array}$ & $\begin{array}{l}\text { Affects younger women, ovarian } \\
\text { hyperandrogenism, virilisation, hirsu- } \\
\text { tism, menstrual cycle and fertility } \\
\text { disorders, acanthosis nigricans, severe } \\
\text { insulin resistance, diabetes mellitus }\end{array}$ & $\begin{array}{l}\text { Insulin receptor gene mutations or } \\
\text { other target-cell defects in its } \\
\text { action }\end{array}$ \\
\hline $\begin{array}{c}\text { Insulin } \\
\text { resistance type B }\end{array}$ & $\begin{array}{l}\text { Affects older } \\
\text { associated withen, may be } \\
\text { disorders }\end{array}$ & $\begin{array}{l}\text { Autoimmune mechanism - the } \\
\text { presence of antibodies against } \\
\text { insulin receptor }\end{array}$ \\
\hline $\begin{array}{l}\text { Rabson- } \\
\text { Mendenhall } \\
\text { Syndrome }\end{array}$ & $\begin{array}{l}\text { Insulin resistance type A features, } \\
\text { dental dysplasia, pituitary hyperplasia, } \\
\text { physical growth disorders, diabetes } \\
\text { mellitus, precocious puberty, growth } \\
\text { retardation, renal disorders and } \\
\text { malfunction, death in the first or second } \\
\text { decade of life due to the developing } \\
\text { diabetic ketoacidosis }\end{array}$ & $\begin{array}{l}\text { Insulin receptor gene mutations } \\
\text { (autosomal recessive inheritance) } \\
\text { or other target-cell defects in } \\
\text { insulin action; other defects also } \\
\text { possible }\end{array}$ \\
\hline $\begin{array}{c}\text { Donohue } \\
\text { Syndrome } \\
\text { (leprehaunism) }\end{array}$ & $\begin{array}{l}\text { The most severe form of insulin } \\
\text { resistance, intrauterine growth } \\
\text { retardation, elf-like face features, } \\
\text { hypertrichosis, depletion of adipose } \\
\text { tissue, sexual organs enlargement, } \\
\text { diabetes mellitus due to } \\
\text { hyperinsulinism, cardiomyopathy, liver, } \\
\text { spleen and ovaries hypertrophy, } \\
\text { hyperglycemia, mental retardation, lack } \\
\text { of diabetic ketoacidosis, death in the } \\
\text { first several years of life during infancy } \\
\text { and in the early childhood }\end{array}$ & $\begin{array}{l}\text { Insulin receptor gene mutations } \\
\text { (autosomal recessive inheritance), } \\
\text { mutations in other genes encoding } \\
\text { for growth factors receptors or } \\
\text { signal transduction proteins of } \\
\text { common pathways in which } \\
\text { growth factors also contributes } \\
\text { are also possible }\end{array}$ \\
\hline $\begin{array}{l}\text { Congenital } \\
\text { generalized } \\
\text { lipodystrophy } \\
\text { (lipoatrophy) }\end{array}$ & $\begin{array}{l}\text { Total lipoatrophy, insulin resistance } \\
\text { type A features possible, liver and } \\
\text { spleen hypertrophy, cardiomyopathy, } \\
\text { features of acromegaly, mental } \\
\text { retardation, hypertriglyceridaemia, } \\
\text { hyperandrogenism, bone cysts }\end{array}$ & $\begin{array}{l}\text { Mutations in } A G P A T 2 \text { and seipin } \\
\text { genes, due to lack of these } \\
\text { mutations in some patients, other } \\
\text { mutations in other genes are also } \\
\text { possible }\end{array}$ \\
\hline
\end{tabular}




\begin{tabular}{|c|c|c|}
\hline SYNDROME & CLINICAL FEATURES & MOLECULAR MECHANISM \\
\hline $\begin{array}{c}\text { Congenital } \\
\text { partial } \\
\text { lipodystrophy }\end{array}$ & $\begin{array}{l}\text { Changes in adipose tissue distribution } \\
\text { associated with lipoatrophy or } \\
\text { lipohypertrophy, insulin resistance type } \\
\text { A features also possible, liver and } \\
\text { spleen hypertrophy, cardiomyopathy, } \\
\text { muscle dystrophy, disorders with } \\
\text { nervous signalling, features of } \\
\text { acromegaly or hypertriglyceridaemia }\end{array}$ & $\begin{array}{l}\text { Mutations in LMNA gene } \\
\text { encoding for nuclear lamina } \\
\text { proteins }-\mathrm{A} \text { and } \mathrm{C} \text { lamin } \\
\text { (autosomal dominant inheritance), } \\
\text { in ZMPSTE24 gene encoding for } \\
\text { zinc metalloproteinase or in } \\
P P A R \gamma \text { gene encoding for nuclear } \\
\text { receptor activated by peroxisome } \\
\text { proliferators }\end{array}$ \\
\hline
\end{tabular}

One of such syndromes is Rabson-Mendenhall syndrome (RMS), which was first described in 1956 [113, 114] and since then, only several cases have subsequently been described. While the genetic background of this extremely rare, autosomal recessive disorder is not fully understood, several cases are linked to mutations in insulin receptor gene. The characteristic features of RabsonMendenhall syndrome include severe insulin resistance developing early in childhood, diabetes mellitus, acanthosis nigricans, polycystic ovaries and virilisation in female patients. Other manifestatations include leprechaunism [78], dental dysplasia, abnormal physical development, precocious puberty, pineal hyperplasia with melatonin secretion changes [22, 49, 68]. Moreover, these symptoms are associated with postnatal growth retardation, motor skills difficulties, speech and hearing problems, fast growing nails, hypertrichosis and other defects such as renal abnormalities [50]. Due to this extremely severe form of insulin resistance and, in turn, diabetic ketoacidosis, such patients die in the first or second decade of their life, before age of 16 [152].

Numerous homozygous and heterozygous mutations in the INSR gene have been described for patients diagnosed for Rabson-Mendenhall syndrome which result in receptor dysfunction in extracellular ligand binding domain and in intracellular domain possessing tyrosine kinase activity. In one case, the affinity of insulin binding is lowered or even completely inhibited, whereas in another case, the mutation lead to the insulin transduction defects inside the cell.

Apart from Rabson-Mendenhall syndrome, other forms of insulin resistance which differ in their severity are also connected with INSR gene mutations (Table 1).

In the case of insulin resistance type $\mathbf{A}$, observed in women, diabetes mellitus may develop as a result of insulin receptor down-regulation or defects in its function [150]. Characteristic features, apart from diabetes mellitus, additional disease symptoms include: hyperandrogenism, virilisation, hirsutism, menstrual cycle and fertility disorders $[62,97]$. 
In turn, antibodies raised against insulin receptor are responsible for insulin resistance type $\mathbf{B}$. This form of insulin resistance may coincide with other disorders such as systemic lupus erythematosus [6, 117].

Another example of the most severe form of insulin resistance associated with a lack of insulin binding by its receptor is leprechaunism (Donohue syndrome), which is an autosomal recessive disease, similar to RMS [2, 7, 26, 59, 78]. Features characteristic for this syndrome include: disorders with glucose metabolism, diabetes mellitus, growth and mental retardation, polycystic ovaries in females, hypertrichosis, adipose tissue depletion and acanthosis nigricans. Children suffering from leprechaunism usually die within the first few several years after birth.

\section{Pathogenetic relationships of lipodystrophies syndromes with insulin resistance}

Congenital lipodystrophies are rare autosomal recessive or dominant genetic disorders which are characterized by the selective differing in its severity of adipose tissue depletion. A common feature of such disorders - extreme hypertriglyceridaemia may indicate a role of adipose tissue in lipid homeostasis. As hypertriglyceridaemia results from an increase in very-low-density-lipoproteins synthesis in liver, low-fatty diets are beneficial in patients with congenital lipodystrophy [138].

Lipodystrophy may also be frequently associated with severe insulin resistance, diabetes mellitus and liver steatosis. Lipodystrophy may be congenital which includes congenital generalized lipodystrophy (CGL) (lipoatrophy) and familial partial lipodystrophy (FPL), or acquired. In recent years, three loci responsible for congenital generalized lipodystrophies have been discovered which include $A G P A T 2$, a gene encoding 1-acylglycerol-3-phosphate-O-acyltransferase 2 and BSCL2 [40].

Berardinelli-Seip Congenital Lipodystrophy type 2 (BSCL2) is the most severe form of lipodystrophy. This recessive disorder with almost total lipoatrophy is due to a mutation in the cell-autonomous regulator of adipogenesis, BSCL2 [147, 111]. Interestingly, four other loci were connected with partial congenital lipodystrophies including $L M N A$ a nuclear lamin protein - A and C lamin), PPARG $(P P A R \gamma)$ a peroxisome proliferator-activated receptor gamma, and ZMPSTE24 a zinc metalloproteinase [40].

In patients with Dunnigan-type Familial Partial Lipodystrophy (FPLD; OMIM ID: 151660) a missence mutation (R482Q) in LMNA was shown to be correlated with hyperinsulinism and disorders in blood plasma lipids (increase in blood plasma triglycerids, decreased HDL cholesterol and no changes in general and LDL cholesterol concentration) preceding blood plasma glucose disorders [51]. 


\section{SUMMARY}

In summary, various disorders including severe and extremely rare forms of insulin resistance such as Rabson-Mendenhall syndrome or Donohue syndrome may be a result from mutations in insulin receptor gene. The effects of disruptions to this important protein required to maintain homeostasis may include a decrease in insulin binding, changes in tyrosine kinase activity of the $\beta$ subunit, accompanied by signal transduction defects, defects in receptor maturation and folding, improper distribution of insulin receptor in plasma membrane [151], or disorders with receptor internalisation and/or its accelerated degradation.

Molecular studies including genetic analysis of insulin receptor gene and its transcript are a powerful tool in prenatal diagnostics and in pregnancy planning (testing for a mutation carrier). It is possible that additional analysis of proteins involved in insulin response and factors regulating insulin receptor gene expression as well as those involved in transcript maturation (including yet unidentified microRNAs) will aid in the understanding of the molecular mechanisms underlying various forms of insulin resistance as well as to better treatment.

\section{ACKNOWLEDGMENTS}

This work was supported by Badania Statutowe grant of the Department of Pediatric Endocrinology and Diabetology, Poznan University of Medical Sciences (502-01-01104118-06037).

\section{REFERENCES}

[1] ADJEI AA, HIDALGO M. Intracelllular signal transduction pathwayay proteins as targetsets for cancencer. therapy. J Clin Oncol 2005; 23: 5386-5403.

[2] ÁL-GAZALI LI, KHALIL M, DEVADAS K. A syndrome of insulin resistance resembling leprechaunism in five sibs of consanguineous parents. J Med Genet 1993; 30: 470-475.

[3] ARAKI E, SHIMADA F, UZAWA H, MORI M, EBINA Y. Characterization of the promoter region of the human insulin receptor gene. Evidence for promoter activity. J Biol Chem 1987; 262(33): 16186-16191.

[4] ARAKI E, MURAKAMI T, SHIROTANI T, KANAI F, SHINOHARA Y, SHIMADA F, MORI M, SHICHIRI M, EBINA Y. A cluster of four Sp1 binding sites required for efficient expression of the human insulin receptor gene. J Biol Chem 1991; 266: 3944-3948.

[5] ARIDOR M, BALCH WE. Integration of endoplasmic reticulum signaling in health and disease Nat Med 1999; 5: 745-751.

[6] ARIOGLU E, ANDEWELT A, DIABO C, BELL M, TAYLOR SI, GORDEN P. Clinical course of the syndrome of autoantibodies to the insulin receptor (type B insulin resistance): a 28 -year perspective. Medicine (Baltimore) 2002; 81: 87-100. 
[7] BACKELJAUW PF, ALVES C, EIDSON M, CLEVELAND W, UNDERWOOD LE, DAVENPORT ML. Effect of intravenous insulin-like growth factor I in two patients with leprechaunism. Pediatr Res 1994; 36: 749-754.

[8] BALVAY L, LIBRI D, FISZMAN MY. Pre-mRNA secondary structure and the regulation of splicing. BioEssays 1993; 15: 165-169.

[9] BARBETTI F, GEJMAN PV, TAYLOR SI, RABEN N, CAMA A, BONORA E, PIZZO P, MOGHETTI P, MUGGEO M, ROTH J. Detection of mutations in insulin receptor gene by denaturing gradient gel electrophoresis. Diabetes 1992; 41: 408-415.

[10] BENYOUCEF S, SURINYA KH, HADASCHIK D, SIDDLE K. Characterization of insulin/IGF hybrid receptors: contributions of the insulin receptor L2 and Fn1 domains and the alternatively spliced exon 11 sequence to ligand binding and receptor activation. Biochem J 2007; 403: 603-613.

[11] BLACK DL. Mechanisms of alternative pre-messanger RNA splicing. Аппи Rev Biochem 2003 72: 291-336.

[12] BRUNETTI A, MADDUX BA, WONG KY, GOLDFINE ID. Muscle differentiation is associated with increased insulin receptor biosynthesis and messenger RNA levels. J Clin Invest $1989 ; \mathbf{8 3}$ 192-198.

[13] BRUNETTI A, GOLDFINE ID. Differential effects of fibroblast growth factor on insulin receptor and muscle specific protein gene expression in BC3H-1 myocytes. Mol Endocrinol 1990; 4: 880885 .

[14] [14] BRUNETTI A, FOTI D, GOLDFINE ID. Identification of unique nuclear regulatory proteins for the insulin receptor gene which appear during myocyte and adipocyte differentiation. $J$ Clin Invest 1993; 92: 1288-1295

[15] BRUNETTI A, MANFIOLETTI G, CHIEFARI E, GOLDFINE ID, FOTI D. Transcriptional regulation of human insulin receptor gene by the high-mobility group protein HMGI-Y. FASEB $J$ 2001; 15: 492-500

[16] BRUNING PF, BONFRER JM, VAN NOORD PA, et al. Insulin resistance and breast-cancer risk Int J Cancer 1992; 52: 511-516.

[17] BUCHNER J. Hsp90 \& Co. - a holding for holding. Trends Biochem Sci 1999; 24: 136-141.

[18] BURATTI E, BARALLE M, BARALLE FE. Defective splicing, disease and therapy: searching for. master checkpoints in exon definition. Nucleic Acids Res 2006; 34: 3494-3510.

[19] BURD CG, DREYFUSS G. Conserved structures and diversity of functions of RNA-binding proteins. EMBO J 1994; 13: 1197-1204.

[20] BUSTIN M, REEVES R. High-mobility-group proteins: architectural components that facilitates. chromatin function. Prog Nucleic Acids Res 1996; 54: 35-100.

[21] CACERES JF, STAMM S, Helfman DM, KRAINER AR. Regulation of alternative splicing in vivo by overexpression of antagonistic splicing factors. Science 1994; 265: 1706-1709.

[22] COCHRAN E, YOUNG JR, SEBRING N, DE PAOLLI A. Efficacy. of recombinant methionyl human leptin therapy for the extreme insulin resistance of the Rabson-Mendenhall Syndrome. $J$ Clin Endocrinol Metab 2004; 89(4): 1548-1554.

[23] DE MEYTS P, ROTH J, NEVILLE DM JR, GAVIN JR III, LESNIAK MA. Insulin interactions with. its. receptors: experimental evidence for. negative cooperativity. Biochem Biophys Res Commun 1973; 55(1): 154-161.

[24] DE MEYTS P, BAINCO AR, ROTH J. Site-site interactions among insulin receptors. Characterization of the negative cooperativity. J Biol Chem 1976; 251(7): 1877-1888.

[25] DE MEYTS P, WHITTAKER J. Structural biology of insulin and IGF1 receptors: implications for drug design. Nat Rev Drug Discov 2002; 1: 769-783.

[26] DONOHUE WL, UCHIDA I. Leprechaunism:-_an euphemism for a rare familial disorder. $J$ Pediatr 1954; 45: 505-519.

[27] EBINA Y, ELLIS L, YARNAGIN K, EDERY M, GRAF L, CLAUSER E, OU JH, MASIARZ F, KAN YW, GOLDFINE ID, et al. The human insulin receptor cDNA: the structural basis for hormone-activated transmembrane signalling. Cell 1975; 40: 747-758.

[28] EHRMANN DA, BARNES RB, ROSENFIELD RL. Polycystic ovary syndrome as a form of functional ovarian hyperandrogenism due to dysregulation of androgen secretion. Endocr Rev 1995; 16: 322-353. 
[29] EHRMANN DA, CAVAGHAN MK, IMPERIAL J, STURIS J, ROSENFIELD RL, POLONSKY KS. Effects of metformin on insulin secretion, insulin action, and ovarian steroidogenesis in women with polycystic ovary syndrome. J Clin Endocrinol Metab 1997; 82: 524-530.

[30] EHRMANN DA, SCHNEIDER DJ, SOBEL BE, CAVAGHAN MK, IMPERIAL J, ROSENFIELD RL, POLONSKY KS. Troglitazone improves defects in insulin action, insulin secretion, ovarian steroidogenesis, and fibrinolysis in women with polycystic ovary syndrome. J Clin Endocrinol Metab 1997; 82: 2108-2116.

[31] ELLGAARD L, HELENIUS A. ER guality control: towards an understanding at the molecular. level. Curr Opin Cell Biol 2001; 13: 431-437.

[32] EPERON LP, GRAHAM IR, GRIFFITHS AD, EPERON IC. Effects of RNA__._e-cenondary structucture. on alternative splicing of pre-mRNA: is folding limited to. a region behind the transcribing. RNA polymerase? Cell 1988; 54(3): 393-401.

[33] FAIVRE S, DJELLOUL S, RAYMOND E. New paradigms in anticancer therapy: Targeting. multiple signaling pathways with kinase inhibitors. Semin Oncol 2006; 33: 407-420.

[34] FEDERICI M, PORZIO O, ZUCARO L, et al. Distribution of insulin/insulin-like growth factor-I hybrid receptors in human tissues. Mol Cell Endocrinol 1997; 129: 121-126.

[35] FEDERICI M, LAURO D, D'ADAMO M, et al. Expression of insulin/IGF-I hybrid receptors is increased in skeletal muscle of patients with chronic primary hyperinsulinemia. Diabetes 1998; 47: 87-92.

[36] FEDERICI M, PORZIO O, LAURO D, et al. Increased abundance of insulin/insulin-like growth factor-I hybrid receptors in skeletal muscle of obese subjects is correlated with in vivo insulin sensitivity. J Clin Endocrinol Metab 1998; 83: 2911-2915.

[37] FOTI D, JULIANO R, CHIEFARI E, BRUNETTI A. A nucleoprotein complex containing Sp1, C/EBP $\beta$, and HMGI-Y controls human insulin receptor gene transcription. Moll Cell Biol 2003; 23(8): 2720-2732.

[38] FRASCA F, PANDINI G, SCIACCA L, et al. Insulin receptor isoform A, a newly recognized, high-affinity insulin-like growth factor II receptor in fetal and cancer cells. Mol Cell Biol 1999; 19: 3278-3288.

[39] FREYCHET P, ROTH J, NEVILLE Jr DM. Insulin receptors in the liver: specific binding of $\left[{ }^{125}\right.$ I $]$ insulin to the plasma membrane and its relation to insulin bioactivity. Proc Natl Acad Sci USA 1971 ; 68(8): 1833-1837.

[40] GARG A, AGARWAL AK. Lipodystrophies: Disorders of adipose tissue biology. Biochem Biophys Acta 2009; 91(6): 507-513.

[41] GHAZEERI G, KUTTEH WH, BRYER-ASH M, HAAS D, KE RW. Effect of rosiglitazone on.-. spontaneous and clomiphene citrateinduced ovulation in women with polycystic ovary s. syndrome. Fertil Steril 2003; 79: 562-566.

[42] GIDDINGS SJ, CARNAGHI LR. Insulin receptor gene expression during development: developmental regulation of insulin receptor mRNA abundance in embryonic rat liver and yolk sac, developmental regulation of insulin gene splicing, and comparison to abundance of insulin-like growth factor 1 receptor mRNA. Mol Endocrinol 1992; 6(10): 1665-1672.

[43] GIOVANNONE B, SCALDAFERRI ML, FEDERICI M. et al. Insulin receptor substrate (IRS) transduction system: distinct and overlapping signaling potential. Diabetes Metab Res Rev 2000; 16: 434-441.

[44] GOLLOB JA, SCOTT W, CARTER C, KELLEY SL. Role of Raf kinase in cancer: Therapeutic. potential of targeting the Raf/Mek/Eerk signal transduction pathww. 므. Sem Oncol 2006; 33: 392406.

[45] GRAVELEY BR. Mutually exclusive splicing of the insect Dscam pre-mRNA directed by competing intronic RNA secondary structures. Cell 2005; 123: 65-73.

[46] GUAN KL. The mitogen activated protein kinase signal transduction pathway: from the cell surface to the nucleus. Cell Signal 1994; 6: 581-589.

[47] HAAS DA, CARR BR, ATTIA GR. Effects of metformin on body mass index, menstrual cyclicity, and ovulation induction in women with polycystic ovary syndrome. Fertil Steril 2003; 79: 469481 . 
[48] HANSEN T, BJØRBAEK C, VESTERGAARD H, GRØNSKOV K. Expression of insulin receptor spliced variants and their functional correlates in muscle from patients with non-insulin-dependent diabetes mellitus. J Clin Endocrinol Metab 1993; 77(6): 1500-1505.

[49] HARDAWAY CA, GIBBS NF. What Syndrome Is This? Pediatr Dermatol 2002; 19(3): 267-270.

[50] HARRIS AM, HALL B, KRISS VM, FOWLKES JL, KIESSLING SG. Rabson-Mendenhall. syndrome: medullary sponge kidney, a new component. Pediatr Nephrol 2007; 22: 2141-2144.

[51] HEGELE RA, ANDERSON CM, WANG J, JONES DC, CAO H. Association between nuclear lamin A/C R482Q mutation and partial lipodystrophy with hyperinsulinemia, dyslipidemia, hypertension, and diabetes. Genome Res 2000; 10(5): 652-658.

[52] HELENIUS A, TROMBETTA ES, HEBERT DN, SIMONS JF. Calnexin, calreticulin and the folding of glycoproteins. Trends Cell Biol 1997; 7: 193-200.

[53] HILLER M, ZHANG Z, BACKOFEN R, STAMM S. Pre-mRNA_ secenondary structuctures influencee. exon recognition. PLoS Genet 2007; 3: c204.

[54] HOEY T, WEINZIERL RO, GILL G, CHEN JL, DYNLACHT BD, TJIAN R. Molecular cloning and functional analysis of Drosophila TAF110 reveal properties expected of coactivators. Cell 1993; 72(2): 247-260.

[55] HSU IR, KIM SP, KABIR M, BERGMAN RN. Metabolic syndrome, hyperinsulinemia, and cancer. Am J Clin Nutr 2007; 86(3): Suppl. 867-871.

[56] HU FB, MANSON JE, LIU S, et al. Prospective study of adult onset diabetes mellitus (type 2) and risk of colorectal cancer in women. J Natl Cancer Inst 1999; 91: 542-547.

[57] Insulin receptor no. 147670: defect in insulin receptor, with insulin resistant diabetes mellitus, acanthosis nigricans, and Type A. Online Mendelian Inheritance in Man (OMIM). Johns Hopkins University. Victor A. McKusick. 6/2/1986. http://www.ncbi.nlm.nih.gov/entrez/dispomim.cgi? id $=147670$.

[58] ISHII S, XU Y-H, STRATTON RH, ROE BA, MERLINO GT, PASTAN I. Characterization and. seguence of the promoter region of the human epidermal growth factor receceptor gene. PNA PNS 1985; 82(15): 4920-4924.

[59] JOSPE N, ZHU J, LIU R, LIVINGSTON JN, FURLANETTO RW. Deletion of 3 basepairs resulting in the loss of lysine-121 in the insulin receptor alpha-subunit in a patient with leprechaunism: binding, phosphorylation, and biological activity. J Clin Endocrinol Metab 1994; 79: 1294-1302.

[60] KADOWAKI T, BEVINS CL, CAMA A, OJAMAA K, MARCUS-SAMUELS B, KADOWAKI H, BEITZ L, MCKEON C, TAYLOR SI. Two mutant alleles of the insulin receptor gene in a patient with extreme insulin resistance. Science 1988; 240: 787-790.

[61] KADOWAKI T, KADOWAKI H, RECHLER MM, SERRANO-RIOS M, ROTH J, GORDEN P, et al. Five mutant alleles of the insulin receptor gene in patients with genetic forms of insulin resistance. J Clin Invest 1990; 86: 254-264.

[62] KAHN CR, FLIER JS, BAR RS, ARCHER JA, GORDEN P, MARTIN MM, ROTH J. The syndromes of insulin resistance and acanthosis nigricans. Insulin-receptor disorders in man. $N$ Engl J Med 1976; 294: 739-745.

[63] KALlO A, LAKATOS I, SZIJARTO L. Leprechaunism (Donohue's syndrome). J Pediatr 1965; 66: $372-379$.

[64] KARIN M, HASLINGER A, HOLTGREVE H, RICHARDS RI, KRAUTER P, WESTPHAL HM, BEATO M. Characterization of DNA sequences through which cadmium and glucocorticoid hormones induce human metallothionein-IIA gene. Nature 1984; 308(5959): 513-519.

[65] KELLERER M, SESTI G, SEFFER B, OBERMAIER-KUSSER DE, PONGRATZ L, MOSTHAF L, HARING HU. Altered pattern of insulin receptor isotypes in skeletal muscle membranes of type 2 (non-insulin-dependent) diabetic subjects. Diabetologia 1993; 36: 628-632.

[66] KIM HS, LEE JK, TSAI SY. E1a activation of insulin receptor gene expression is mediated by Sp1- binding sites. Mol Endocrinol 1994; 9: 178-186.

[67] KIM SH, MOORES JC, DAVID D, RESPESS JG, JOLLY DJ, FRIEDMANN T. The organization of the human HPRT gene. Nucleic Acids Res 1986; 14(7): 3130-3118.

[68] KIRBY E, BEALS D. Fibroepithelial papillomatosis ("skin tags") in Rabson-Mendenhall syndrome. J Pediatr Surg 2008; 43: E21-E26. 
[69] KOLCH W. Meaningful relationships: The regulation of the Ras/Raf/Mek/Erk pathway by protein interaction. Biochem J 2000; 351: 289-305.

[70] KOSAKI A, WEBSTER NJ. Effect of dexamethasone on the alternative splicing of the insulin receptor mRNA and insulin action in HepG2 hepatoma cells. J Biol Chem 1993; 268(29): 2199021996.

[71] KOSAKI A, PILLAY TS, XU L, WEBSTER NJG. The B isoform of the insulin receptor signals more efficiently than the A isoform in HepG2 cells. J Biol Chem 1995; 35(1): 20816-20823.

[72] KOSAKI A, NELSON J, WEBSTER NJG. Identification of intron and exon sequences involved in alternative splicing of insulin receptor pre-mRNA. J Biol Chem 1998; 273: 10331-10337.

[73] KRISTENSEN C, WIBERG FC, SCHAFFER L, ANDERSEN AS. Expression and characterization of a 70-kDa fragment of the insulin receptor that binds insulin. J Biol Chem 1998; 273: 1778017786.

[74] KUO H-C, NASIM FH, GRABOWSKI PJ. Control of alternative splicing by the differential binding of U1 small nuclear ribonucleoprotein particle. Science 1991; 252: 1045-1050.

[75] LANGLOIS WJ, SASAOKA T, YIP CC, OLEFSKY JM. Functional characterization of hybrid receptors composed of a truncated insulin receptor and wild type insulin-like growth factor 1 or insulin receptor. Endocrinology 1995; 136: 1978-1986.

[76] LEE JK, TAM JW, TSAI MJ, TSAI SY. Identification of cis- and trans-acting factors regulating the expression of the human insulin receptor gene. J Biol Chem 1992; 267(7): 4638-4645.

[77] LEITNER JW, KLINE T, CAREL K, et al. Hyperinsulinemia potentiates activation of p21Ras by growth factors. Endocrinology 1997; 138: 2211-2214.

[78] Leprechaunism no. 246200: defect in insulin receptor, with Donohue syndrome. Online Mendelian Inheritance in Man (OMIM). Johns Hopkins University. Victor A. McKusick: 6/3/1986. http://www.ncbi.nlm.nih.gov/entrez/dispomim.cgi?id=246200.

[79] LIU K, STAMLER J, MOSS D, et al. Dietary cholesterol, fat, and fibre, and colon-cancer mortality. An analysis of international data. Lancet 1979; 2: 782-785.

[80] LONGO N, WANG Y, SMITH SA, LANGLEY SD, DIMEGLIO LA, GIANELLA-NETO D. Genotype-phenotype correlation in inherited severe insulin resistance. Hum Mol Genet 2002; 11(12): 1465-1475.

[81] MAMULA PW, MC DONALD AR, BRUNETTI A, OKABAYASHI Y, WONG KY, MADDUX BA, LOGSDON C, GOLDFINE ID. Regulating insulin-receptor-gene expression by differentiation. and hormones. Diabetes Care 1990; 13(3): 288-301.

[82] MARINO-BUSLJE C, MARTIN-MARTINEZ M, MIZUGUCHI K, SIDDLE K, BLUNDELL TL. The insulin receptor: from protein sequence to structure. Biochem Soc Trans 1999; 27: 715-726.

[83] MC CLAIN DA. Different ligand affinities of the two insulin receptor splice variants are reflected. in parallel changes in sensitivity for insulin action. Mol Endocrinol 1991; 5: 734-739.

[84] MC DONALD AR, MADDUX BA, OKABAYĀSHI Y, WONG KY, HAWLEY DM, LOGSDON CD, GOLDFINE ID. Regulation of insulin-receptor mRNA levels by glucocorticoids. Diabetes 1987; 36(6):779-781.

[85] MC KEON C, ACCILI D, CHEN H, PHAM T, WALKER GE. A conserved region in the first intron of the insulin receptor gene binds nuclear proteins during adipocyte differentiation. Biochem Biophys Res Commun 1997; 240: 701-706.

[86] MC KEOWN M. Alternative mRNA splicing. Annu Rev Cell Biol 1992; 8: 133-155.

[87] MC KERN NM, LAWRENCE MC, STRELTSOV VA, LOU MZ, ADAMS TE, LOVRECZ GO, ELLEMAN TC, RICHARDS KM, BENTLEY JD, PILLING PA, et al. Structure of the insulin receptor ectodomain reveals a folded-over conformation. Nature 2006; 443: 218-221.

[88] MILOS PM, ZARET KS. A ubiquitous factor is required for C/EBP-related proteins to form stable transcription complexes on an albumin promoter segment in vitro. Genes Dev 1992; 6: 991-1004.

[89] MINK PJ, SHAHAR E, ROSAMOND WD, et al. Serum insulin and glucose levels and breast cancer incidence: the Atherosclerosis Risk in Communities study. Am J Epidemiol 2002; 156: 349352.

[90] MOGHETTI P, CASTELLO R, NEGRI C, TOSI F, PERRONE F, CAPUTO M, ZANOLIN E, MUGGEO M. Metformin effects on clinical features, endocrine and metabolic profiles, and insulin sensitivity in polycystic ovary syndrome: a randomized, double-blind, placebo controlled 6-month trial, followed by open, long-term clinical evaluation. J Clin Endocrinol Metab 2000; 85: 139-146. 
[91] MOLLER DE, YOKOTA A, CARO JF, FLIER JS. Tissue-specific expression of two alternatively spliced insulin receptor mRNAs in man. Mol Endocrinol 1989; 3: 1263-1269.

[92] MOLLER DE, YOKOTA A, PAZIANOS A, FLIER JS. A missense mutation in one allele of the tyrosine kinase domain of the insulin receptor gene is associated with dominantly inherited insulin resistance. (Abstract) Clin Res 1990; 38: 435A

[93] MOLLER DE, COHEN O, YAMAGUCHI Y, ASSIZ R, GRIGORESCU F, EBERLE A, MORROW LA, MOSES AC, FLIER JS. Prevalence of mutations in the insulin receptor gene in subjects with features of the type A syndrome of insulin resistance. Diabetes 1994; 43: 247-255.

[94] MOSTHAF L, GRAKO D, DULL TJ, COUSSENS L, ULLRICH A, MC CLAIN DA. Functionally distinct insulin receptors generated by tissue-specific alternative splicing. EMBO J 1990; 9: 24092413.

[95] MOSTHAF L, VOGT H, HARING U, ULLRICH A. Altered expression of insulin receptor types A and $\mathrm{B}$ in the skeletal muscle of non-insulin-dependent diabetes mellitus patients. Proc Natl Acad Sci USA 1991; 88: $4728-4730$

[96] MURPHY TK, CALLE EE, RODRIGUEZ C, et al. Body mass index and colon cancer mortality in a large prospective study. Am J Epidemiol 2000; 152: 847-854.

[97] MUSSO C, COCHRAN E, MORAN SA, SKARULIS MC, ORAL EA, TAYLOR SI, GORDEN P Clinical course of genetic diseases of the insulin receptor (type A and Rabson-Mendenhall syndromes): a 30 years prospective. Medicine (Baltimore) 2004; 83: 209-222.

[98] MUSSO C, COCHRAN E, JAVOR E, YOUNG J, DEPAOLI AM, GORDEN P. The long-term. effect of recombinant methionyl human leptin therapy on hyperandrogenism and menstrual function in female and pituitary function in male and female hypoleptinemic lipodystrophic. patients. Metabolism 2005; 54: 255-263.

[99] MUSSO C, SHAWKER T, COCHRAN E, JAVOR ED, YOUNG J, GORDEN P. Clinical evidence that hyperinsulinaemia independent of gonadotropins stimulates ovarian growth. Clin Endocrinol 2005; 63: 73-78.

[100] MÜLLER-WIELAND D, VAN DER VORM ER, STREICHER R, KRONE W, SEEMANOVA E, DREYER M, RÜDIGER HW, ROSIPAL SR, MAASSEN JA. An in-frame insertion in exon 3 and a nonsense mutation in exon 2 of the insulin receptor gene associated with severe insulin resistance in a patient with Rabson-Mendenhall syndrome Diabetologia 1993; 36: 1168-1174.

[101] NELSON KK, GREEN MR. Mechanism for cryptic splice site activation during pre-mRNA. splicing. Proc Natl Acad USA 1990; 87: 6253-6525.

[102] NELSON VL, QIN KN, ROSENFIELD RL, WOOD JR, PENNING TM, LEGRO RS, STRAUSS JF, MC ALLISTER JM. The biochemical basis for increased testosterone production in theca cells propagated from patients with polycystic ovary syndrome. J Clin Endocrinol Metab 2001; 86: $5925-5933$.

[103] NESTLER JE. Role of hyperinsulinemia in the pathogenesis of the polycystic ovary syndrome, and. its clinical implications. Semin Reprod Endocrinol 1997; 15: 111-122.

[104] NORGREN S, ZIERATH J, WEDELL A, WALLEBERG-HENRIKSSON H, LUTHMAN H. Regulation of human insulin receptor RNA splicing in vivo. Proc Natl Acad Sci USA 1994; 91: 1465-1469.

[105] NORGREN S, LI LS, LUTHMAN H. Regulation of human insulin receptor RNA splicing in HepG2 cells: effects of glucocorticoid and low glucose concentration. Biochem Biophys Res Commun 1994; 199: 277-284.

[106] NORGREN S, ZIERATH J, GALUSKA D, WALLBERG-HENRIKSSON H, LUTHMAN H. Differences in the ratio of RNA encoding two isoforms of the insulin receptor between control and NIDDM patients. The RNA variant without Exon 11 predominates in both groups. Diabetes 1993; 42: $675-681$

[107] OLSON TS, BAMBERGER MJ, LANE MD. Post-translational changes in tertiary and quaternary structure of the insulin proreceptor: correlation with acquisition of function. J Biol Chem 1998; 263: 7342-7351.

[108] ORAL EA, SIMHA V, RUIZ E, ANDEWELT A, PREMKUMAR A, SNELL P, WAGNER AJ, DEPAOLI AM, REITMAN ML, TAYLOR SI, GORDEN P, GARG A. Leptin-replacement therapy for lipodystrophy. $N$ Engl J Med 2002; 346: 570-578. 
[109] ORAL EA, RUIZ E, ANDEWELT A, SEBRING N, WAGNER AJ, DE PAOLI AM, GORDEN P. Effect of leptin replacement on pituitary hormone regulation in patients with severe lipodystrophy. J Clin Endocrinol Metab 2002; 87: 3110-3117.

[110] OŚWIĘCIMSKA J, ZIORA K, DYDUCH A. Lipodystrofia nabyta i wrodzona. Endokrynologia, Otyłość i Zaburzenia Przemiany Materii 2006; 2(1): 22-29.

[111] PAYNE VA, GRIMSEY N, TUTHILL A, VIRTUE S, GRAY SL, DALLA NORA E, SEMPLE RK, O'RAHILLY S, ROCHFORD JJ. The human lipodystrophy gene BSCL2/seipin may be essential for normal adipocyte differentiation. Diabetes 2008; 57(8): 2055-2060.

[112] PELLECANI A, CHIN M T, WIESEL P, IBANEZ M, PATEL A, YET S-F, HSIEH C-M, PAULAUSKIS JD, REEVES R, LEE M-E, PERRELLA MA. Induction of high mobility group$\mathrm{I}(\mathrm{Y})$ protein by endotoxin and interleukin-1ß in vascular smooth muscle cells. J Biol Chem 1999; 274: $1525-1532$.

[113] RABSON SM, MENDENHALL EN. Familial hypertrophy of pineal body, hyperplasia of adrenal cortex and diabetes mellitus; report of 3 cases. Am J Clin Pathol 1956; 26: 283-290.

[114] Rabson-Mendenhall syndrome. 262190: Pineal hyperplasia, insulin-resistant diabetes mellitus, and somatic abnormalities. Online Mendelian Inheritance in Man (OMIM). Johns Hopkins University. Creation date - Victor A. McKusick: 6/4/1986. http://www.ncbi.nlm.nih.gov/entrez/dispomim.cgi? $\mathrm{id}=262190$.

[115] ROMUALDI D, GUIDO M, CIAMPELLI M, GIULIANI M, LEONI F, PERRI C, LANZONE A. Selective effects of pioglitazone on insulin and androgen abnormalities in normo- and. hyperinsulinaemic obese patients. with polycystic ovary syndrome. Hum Reprod $200 \overline{3} ; 1 \mathbf{1 8}: 1210-$ 1218.

[116] ROSE DP, KOMNINOU D, STEPHENSON GD. Obesity, adipocytokines, and insulin resistance in breast cancer. Obes Rev 2004; 5(3): 153-165.

[117] ROSENSTEIN ED, ADVANI S, REITZ RE, KRAMER N. The prevalence of insulin receptor. antibodies in patients with systemic lupus erythematosus and related conditions. $J$ Clin Rheumatol 2001; 7: 371-373.

[118] ROTH SI, SCHEDEWIE HK, HERZBERG VK, OLEFSKY J, ELDERS MJ, RUBENSTEIN A. Cutaneous manifestations of leprechaunism. Arch Dermatol 1981; 117: 531-535.

[119] RUBIN CM, HOUCK CM, DENINIGER PL, FRIEDMANN T, SCHMID CW. Partial nucleotide sequence of the 300-nucleotide interspersed repeated human DNA sequences. Nature 1980; 284: 372-374.

[120] RUDDON RW, BEDOWS E. Assisted protein folding. J Biol Chem 1997; 272: 3125-3128.

[121] RUDMAN D, FELLER AG, NAGRAJ HS, et al. Effects of human growth hormone in men over 60 years old. $N$ Engl J Med 1990; 323: 1-6.

[122] SAITOH T, YANAGITA T, SHIRAISHI S, YOKOO H, KOBAYASHI H, MINAMI S-I, ONITSUKA T, WADA A. Down-regulation of cell surface insulin receptor and insulin receptor substrate-1 phosphorylation by inhibitor of $90-\mathrm{kDa}$ Heat-Shock Protein family: endoplasmic reticulum retention of monomeric insulin receptor precursor with calnexin in adrenal chromaffin cells. Mol Pharmacol 2002; 62(4): 847-855.

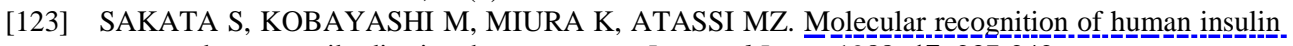
receptor by autoantibodies in a human serum. Immunol Invest 1988; 17: 237-242.

[124] SALMERON J, ASCHERIO A, RIMM E. Dietary fiber, glycemic load, and risk of NIDDM ․ㅡ.men. Diabetes Care 1997; 20: 545.

[125] SÄWKA-VERHELLE D, TARTARE-DECKERT S, WHITE MF, VAN OBBERGHEN E. Insulin receptor substrate-2 binds to the insulin receptor through its phosphotyrosine-binding domain and through a newly identified domain comprising amino acid J Biol Chem 1996; 271: 5980-5983.

[126] SAVKUR RS, PHILIPS AV, COOPER TA. Abberant regulation of insulin receptor alternative. splicing is associated with insulin resistance in myotonic dystrophy. Nat Genet 2001; 29: 40-47.

[127] SCHLESSINGER J. Ligand-induced,. receptor-mediated dimerization. and. activation. of. EGF. receptor. Cell 2002; 110: 669-672.

[128] SCIACCA L, COSTANTINO A, PANDINI G, et al. Insulin receptor activation by IGF-II inbreast cancer: evidence for a new autocrine/paracrine mechanism. Oncogene 1999; 18: 2471-2479.

[129] SEELY BL, REICHART DR, TAKATA Y, YIP CC, OLEFSKY JM. A functional assessment of insulin/insulin-like growth factor-I hybrid receptors. Endocrinology 1995; 136: 1635-1641. 
[130] SEINO S, BELL GI. Alternative splicing of human insulin receptor messenger RNA. Biochem Biophys Res Commun 1989; 159: 312-316.

[131] SEINO S, SEINO M, NISHI S, BELL GI. Structure of the human insulin receptor gene and of its promoter. Proc Natl Acad Sci USA 1989; 86: 114-118.

[132] SELL SM, REESE D, OSSOWSKI VM. Insulin-inducible changes in insulin receptor mRNA splice variants. J Biol Chem 1994; 269: 30769-30772.

[133] SEN S, TALUKDAR I, WEBSTER NJG. SRp20 and CUG-BP1 modulate insulin receptor exon 11 alternative splicing. Moll Cell Biol 2009; 29(3): 871-880.

[134] SESTI G, MARINI MA, MONTEMURRO A, et al. Evidence that two naturally occuring human insulin receptor alpha-subunit variants are immunologically distinct. Diabetes 1992; 41: 6-11.

[135] SESTI G, TULLIO AN, MARINI MA, et al. Role of the exon 11 of the insulin receptor gene on insulin binding identified by antipeptide antibodies. Moll Cell Endocrinol 1994; 101: 121-127.

[136] SESTI G, TULLIO AN, D'ALFONSO R, et al. Tissue-specific expression of two alternatively spliced isoforms of the human insulin receptor protein. Acta Diabetologica 1994; 31: 59-65.

[137] SESTI G, FEDERICI M, LAURO D, SBRACCIA P, LAURO R. Molecular mechanism of insulin resistance in type 2 diabetes mellitus: role of the insulin receptor variant forms. Diabetes Metab Res Rev 2001; 17: 363-373.

[138] SIMHA V, GARG A. Inherited lipodystrophies and hypertriglyceridemia. Curr Opin Lipidol 2009; 20(4): 300-308.

[139] SINGER-SAM J, KEITH DH, TANI K, SIMMER RL, SHIVELY L, LINDSAY S, YOSHIDA A RIGGS AD. Sequence of the promoter region of the gene for human X-linked 3-phosphoglycerate kinase. Gene 1984; 32: 409-417.

[140] SINGH NN, SINGH RN, ANDROPHY EJ. Modulating role of RNA structure in alternative splicing of a critical exon in the spinal muscular atrophy genes. Nucleic Acids Res 2007; 35(2):371389.

[141] SKUPIEŃ J, MAŁECKI MT. Rozbudowywanie podziału cukrzycy - nowe podtypy i możliwości lecznicze. Diabetologia Praktyczna 2007; 8(1): 1-12.

[142] SOLNICK D. Alternative splicing caused by RNA secondary structure. Cell 1985; 43: 667-676

[143] SOLNICK D, LEE SI. Amount of RNA secondary structure required to induce an alternative splice. Moll Cell Biol 1987; 7: 3194-3198.

[144] SOOS MA, FIELD CE, SIDDLE K. Purified hybrid insulin/insulin-like growth factor-I receptors bind insulin-line growth factor-I but not insulin, with high affinity. Biochem J 1993; 290: 419-426.

[145] STANDAERT ML, SCHIMMEL SD, POLLET RJ. The development of insulin receptors and responses in the differentiating non-fusing muscle cell line BC3H-1. J Biol Chem 1984; 259: 23372345 .

[146] STEFANOVSKY VY, PELLETIER G, HANNAN R, GAGNON-KUGLER T, ROTHBLUM LI, MOSS T. An immediate reponse of ribosomal transcription to growth factor stimulation in mammals is mediated by ERK phosphorylation of UBF. Mol Cell 2001; 8: 1063-1073.

[147] SZYMANSKI KM, BINNS D, BARTZ R, GRISHIN NV, LI WP, AGARWAL AK, GARG A, ANDERSON RG, GOODMAN JM. The lipodystrophy protein seipin is found at endoplasmic. reticulum lipid droplet junctions and is important for droplet morphology. Proc Natl Acad Sci USA 2007; 104(52): 20890-20895.

[148] TALUKDAR I, SEN S, WEBSTER N. SRp20, hnRNP A1 and F regulate alternative splicing of insulin receptor via binding to the intronic regulatory elements. FASEB J 2008; 22: 601.1 .

[149] TANIGUCHI CM, EMANUELLI B, KHAN CR. Critical nodes in signalling pathways: insights. into insulin action. Nat Rev Mol Cell Biol 2006; 7: 85-96.

[150] TEWARI DS, COOK DM, TAUB R. Characterization of the promoter region and 3' end of the human insulin receptor gene. J Biol Chem 1989; 264(27): 16238-16245.

[151] THIEL CT, KNEBEL B, KNERR I, STICHT H, MÜLLER-WIELAND D, ZENKER M, REIS A, DÖRR H-G, RAUCH A. Two novel mutations in the insulin binding subunit of the insulin receptor gene without insulin binding impairment in a patient with Rabson-Mendenhall syndrome. Mol Genet Metab 2008; 94: 356-362.

[152] TUTHILL A, SEMPLE RK, DAY R, SOOS M, SWEENEY E, SEYMOUR PJ, DIDI M, O'RAHILLY S. Functional characterization of a novel insulin receptor mutation contributing to Rabson-Mendenhall syndrome. Clin Endocrinol 2007; 66: 21-26. 
[153] ULLRICH A, BELL JR, CHEN EY, HERRERA R, PETRUZZELLI LM, DULL TJ, GRAY A COUSSENS L, LIAO YC, TSUBOKAWA M, et al. Human insulin receptor and its relationship to the tyrosine kinase family of oncogenes. Nature $1985 ; 313$ : 756-761.

[154] VOGT B, CARRASCOSA JM, ERMEL B, ULLRICH A, HARING HU. The two isotypes of the human insulin receptor (HIR-A and HIR-B) follow different internalization kinetics. Biochem Biophys Res Commun 1991; 177: 1013-1018.

[155] VOJTEK AB, DER CJ. Increasing complexity of the Ras signaling pathway. J Biol Chem 1998; 273: $19925-19928$.

[156] VELAZQUEZ EM, MENDOZA S, HAMER T, SOSA F, GLUECK CJ. Metformin therapy in polycystic ovary syndrome reduces hyperinsulinemia, insulin resistance, hyperandrogenemia, and systolic blood pressure, while facilitating normal menses and pregnancy. Metabolism 1994; 43: 647-654.

[157] WALDHAUSER F, WEISSENBACHER G, FRISCH H, POLLAK A. Pulsatile secretion of gonadotropins in early infancy. Eur J Pediatr 1981; 137: 71-74.

[158] WEBSTER NJG, EVANS L-G, CAPLES M, ERKER L, CHEW SL. Assembly of splicing complexes on exon 11 of the human insulin receptor gene does not correlate with splicing efficiency in-vitro. BMC Mol Biol 2004; 5(7).

[159] WHITE MF. The insulin signaling system and the IRS proteins. Diabetologia 1997; 40: Suppl. 217.

[160] WHITE MF, KAHN CR. The insulin signaling system. J Biol Chem 1994; 269: 1-4.

[161] YAMAGUCHI Y, FLIER JS, YOKOTA A, BENECKE H, BACKER JM, MOLLER DE. Functional properties of two naturally occurring isoforms of the human insulin receptor in Chinese. hamster ovary cells. Endocrinology 1991; 129: 2058-2066.

[162] YAMAGUCHI Y, FLIER JS, BENECKE H, RANSIL BJ, MOLLER DE. Ligand-binding properties of the two isoforms of the human insulin receptor. Endocrinology 1993; 132: 1132-1138.

[163] ZYROMSKI NJ, MATHUR A, PITT HA, WADE TE, WANG S, NAKSHATRI P, SWARTZ BASILE DA, NAKSHATRI H. Obesity potentiates the growth and dissemination of pancreatic cancer. Surgery 2009; 146(2): 258-263.

Correspondence author:

Aleksandra Rojek, PhD in Molecular Biology

Home address: 92/51 M.C. Sklodowskiej-Curie Street, 85-733 Bydgoszcz

Correspondence address: Os. Batorego 5D/43, 60-687 Poznan

Work address:

Poznan University of Medical Sciences, $2^{\text {nd }}$ Chair of Pediatrics,

Department of Pediatric Endocrinology and Diabetology,

Molecular Endocrinology Laboratory

27/33 Szpitalna Street

60-572 Poznan, Poland

phone number: $+48618491481 / 424$

phone/fax.: +48618480291

mobile phone: +48 502-649-794

e-mail: aleksandra.rojek@gmail.com 